\title{
WOMEN, MOTHERS, AND THE LAW OF FRIGHT: A HISTORY $\dagger$
}

\author{
Martha Chamallas* with Linda K. Kerber**
}

The law of torts values physical security and property more highly than emotional security and human relationships. This apparently gender-neutral hierarchy of values has privileged men, as the traditional owners and managers of property, and has burdened women, to whom the emotional work of maintaining human relationships has commonly been assigned. The law has often failed to compensate women for recurring harms - serious though they may be in the lives of women - for which there is no precise masculine analogue. This phenomenon is evident in the history of tort law's treatment of frightbased physical injuries, a type of claim historically brought more often by female plaintiffs. There are two paradigm cases of fright-based physical injury: the pregnant plaintiff who suffers a miscarriage or stillbirth as a result of being frightened and the mother who suffers nervous shock when she witnesses her child's injury or death. These claims were classified in the law as emotional harms and a number of special doctrinal obstacles were created to contain recovery in such cases.

In the nineteenth century, tort claims for fright-based injuries were governed by the contemporaneous physical impact rule. Under this rule, a plaintiff could recover for a fright-based injury only if her fright-based harm were coupled with a direct physical impact. ${ }^{1}$ Near misses, regardless of the severity of the harm they caused, were not

$\dagger$ (C) 1990 by Martha Chamallas and Linda K. Kerber

* Chair, Women's Studies Program and Professor of Law, University of Iowa. B.A. 1971, Tufts; J.D. 1975, Louisiana State University. - Ed.

** May Brodbeck Professor in the Liberal Arts and Professor of History, University of Iowa. A.B. 1960, Barnard College; M.A. (History) 1961, New York University; Ph.D. (History) 1968, Columbia University. - Ed.

We are deeply indebted to Mary Louise Fellows, Peter Shane, Dirk Hartog, and Martha Minow for their help in shaping the substance and presentation of this article. We are also very grateful to the Institute of Legal Studies at the University of Wisconsin for its prepublication distribution of our manuscript as a working paper and to Peter Carstensen and Carin Clauss for their insightful comments and helpful criticism of our working paper at the Institute's colloquium. We also benefited from thoughtful comments and additions to our working paper from Mary Dudziak, Richard Kerber, Sylvia Law, Jean Love, Judith Walzer Leavitt, and Barbara Sicherman. Our research assistants, Dan Magel, John Murray, and Mary Tabor also made valuable contributions to this article.

1. See infra Part II for a fuller account of the impact rule. 
actionable. The demise of the impact rule in the 1930s provided a greater opportunity for recovery for fright-based harms, including fright-induced miscarriage or stillbirth. But only since 1968 and the California Supreme Court's landmark decision in Dillon v. Legg ${ }^{2}-$ and only in some jurisdictions - has it been possible for a mother who witnesses the negligent injuring of her child to recover for her own fright-induced injuries.

Fright, of course, is not gender-specific. Men have suffered heart attacks and other serious injuries from fright, arising both from concern for themselves and for their loved ones. The relevant tort rules have never been explicitly gender-based. Historically, however, women have tended to bring claims for fright-based injuries far more often than for men. ${ }^{3}$

Until quite recently, courts and commentators indicated an awareness of this gender disparity, although they lacked a feminist framework in which to assess its significance in shaping the law. The present state of legal scholarship, however, has lost sight of the gendered aspect of fright law. The story now told by contemporary treatises and casebooks no longer takes account of gender.

This article presents a gendered history of the law's treatment of fright-based physical injuries. Our goal is to connect the law of fright to the changing cultural and intellectual forces of the twentieth century. Through a feminist lens, we reexamine the accounts of the legal treatment of fright-based injuries offered by Victorian-era jurists, ${ }^{4}$ traditionalist legal scholars of the first two decades of the twentieth century, ${ }^{5}$ a legal realist in the $1930 \mathrm{~s},{ }^{6}$ and a Freudian medical-legal commentator from the $1940 \mathrm{~s},{ }^{7}$ all of whom helped to shape presentday tort doctrine. We conclude with an account of Dillon v. Legg, ${ }^{8}$ in which the California Supreme Court recognized Margery Dillon's right to recover for the harm she suffered from seeing her daughter killed by a negligent driver.

This examination of the history of the law of fright shows that gendered thinking has influenced the law, but has remained unexamined. We make three basic observations. First, we claim that the legal

2. 68 Cal. 2d 728, 441 P.2d 912, 69 Cal. Rptr. 72 (1968).

3. See infra notes 120,148 , and accompanying text.

4. See infra notes 29-64 and accompanying text.

5. See infra notes $65-87$ and accompanying text.

6. See infra notes 104-23 and accompanying text.

7. See infra notes $124-58$ and accompanying text.

8. 68 Cal. 2d 728, 441 P.2d 912, 69 Cal. Rptr. 72 (1968); see infra notes $200-25$ and accompanying text. 
categories of "physical" and "emotional" harm are not unrelated to the gender of the victims. Women who have suffered fright-induced physical injuries have been disadvantaged by the legal classification of their injuries as emotional harm. Second, we demonstrate how the legal system has placed women's fright-based injuries at the margins of the law by describing women's suffering for the injury and death of their unborn and born children as remote, unforeseeable, and unreasonable. Finally, we raise the possibility that the claims of female plaintiffs in these fright cases - plaintiffs such as Margery Dillon should be viewed as women's rights claims, as attempts to pressure the legal system to recognize and value the interests of women. By constructing a gendered history of this legal claim, we aspire to reclaim Dillon for women and to contribute to a feminist reconstruction of tort law.

\section{The Gendering of Harm: Eariy Legal Constructions OF EMOTIONAL INJURY}

An old English case, Lynch v. Knight, ${ }^{9}$ is famous for originating the general proposition that mental disturbance alone does not qualify as a legally cognizable harm. Lynch, decided in 1861, involved a claim of defamation; Jane Knight charged that the defendant had turned her husband against her by falsely accusing her of immorality. The court dismissed her claim because the special damage Jane Knight alleged - that her husband forced her to leave their home - was not, in the court's view, a reasonably foreseeable response to the slander.

To the contemporary eye, the Lynch court's refusal to compensate for emotional harm appears to apply equally to men and women. However, there was a gendered dimension to the legal notion of mental disturbance as it was used in Lynch. The opinions of the judges in Lynch displayed a consciousness of gender difference and used the dichotomy of physical and emotional harm to marginalize the interests of women. The opinions demonstrated that categorization of a legal harm is an active process: in a gendered world, injuries are socially constructed so that the gender of the person claiming a loss can affect the legal conceptualization of the harm. Additionally, Lynch is valuable because it shows how gender differences can be translated into gender disadvantage.

Lord Wensleydale's opinion in Lynch illustrates this process of gender differentiation and disadvantage. He explained the common

9. IX H.L. Cas. 576, 11 Eng. Rep. 854 (1861). 
law rule that permitted husbands, but not wives, to recover for loss of spousal consortium:

[T] he benefit which the husband has in the consortium of the wife[] is of a different character from that which the wife has in the consortium of the husband. The relation of the husband to the wife is in most respects entirely dissimilar from that of the master to the servant, yet in one respect it has a similar character. The assistance of the wife in the conduct of the household of the husband, and in the education of his children, resembles the service of a hired domestic, tutor or governess; is of material value, capable of being estimated in money; and the loss of it may form the proper subject of an action, the amount of compensation varying with the position in society of the parties. This property is wanting in none. It is to the protection of such material interests that the law chiefly attends.

Mental pain or anxiety the law cannot value, and does not pretend to redress, when the unlawful act complained of causes that alone ....

The loss of such service of the wife, the husband, who alone has all the property of the married parties, may repair by hiring another servant; but the wife sustains only the loss of the comfort of her husband's society and affectionate attention, which the law cannot estimate or remedy. She does not lose her maintenance, which he is bound still to supply .....10

Because Lord Wensleydale understood the wife's services as "material," he found that the husband lost a pecuniary, compensable benefit when his wife was injured through the negligence of another. In contrast, Wensleydale characterized the loss the wife sustained when her husband was injured solely as "mental" and "emotional" and, accordingly, denied her a cause of action.

The decision to classify the husband's loss as "material" was not logically compelled, even though the husband was regarded as the legal owner of the assets of the patriarchal family. It would have been as defensible to regard the wife's services as nonpecuniary, given that her work was unpaid and difficult to separate from her love and affection. ${ }^{11}$ What is now regarded as an identical injury suffered by both

10. 11 Eng. Rep. at 863.

11. The court may have viewed its denial of compensation for emotional harm as genderneutral because technically neither spouse could recover for losses labeled as nonpecuniary. The gendered nature of recovery, however, stemmed from the initial classification of the services performed by each spouse. The husband's economic support of his wife was called pecuniary; the wife's household services were likewise designated as pecuniary, despite their emotional dimension. Under common law, each of these services, of course, was legally owned by the husband and the husband alone. The loss of each service was treated as a specifically male injury. The wife was not regarded as the injured party when her husband's earning capacity was impaired. The injuries the wife sustained, however, when her husband no longer was able to perform his domestic role were called nonpecuniary. His day-to-day household involvement was not given a pecuniary value, at least insofar as the loss of such activities was viewed as a loss to the wife. The law not only limited compensation to pecuniary losses, it defined what would count as a "pecuniary" loss in part by reference to the gender of the person seeking compensation. 
spouses - loss of spousal consortium - was then gender-differentiated. When the husband was the plaintiff, the loss was viewed as material harm; when the wife sought recovery, the loss was called emotional harm. This legally constructed asymmetry resulted in gender disadvantage to women.

A second Lynch opinion delegitimated women's harm by designating it as less tangible and more ephemeral than that experienced by men. Lord Campbell's opinion sought to explain why the common law allowed husbands but not wives to recover for the tort of criminal conversation - the claim brought against a defendant for having sexual intercourse with the plaintiff's spouse. While Campbell did not believe that the husband's claim in these cases rested on the loss of material services, he nevertheless viewed the harm as gender-distinct:

The wife is not the servant of the husband, and the action for criminal conversation by the husband does not, like the action by a father for seduction of a daughter, rest on any such fiction as a loss of the services of the wife. The better opinion is that a wife could not maintain or join in an action for criminal conversation against the paramour of her husband who had seduced him. But I conceive that this rests on the consideration that, by the adultery of the husband, the wife does not necessarily lose the consortium of her husband; for she may, and, under certain circumstances, she ought to condone and still enjoy his society; whereas condonation of conjugal infidelity is not permitted to the husband, and, by reason of the injury of the seducer, the consortium with the wife is necessarily for ever lost to the husband. ${ }^{12}$

Campbell's view of the tortious consequences of adultery explicitly incorporated a double standard of sexual morality. Adultery for men was forgivable; the same conduct on the part of women was not. Campbell analogized the husband's injury resulting from a wife's adultery to the loss of property - a total deprivation that occurred regardless of the husband's subjective response. He relegated the wife's injury to the noncompensable class of hurt feelings. Such an injury was less permanent in nature and was viewed as largely dependent on the wife's subjective response. By locating the wife's injury within her own mind, the court could dismiss the harm and blame the victim for not mitigating her own injuries. The court traced the wife's harm to

12. 11 Eng. Rep. at 859-60. Lord Campbell's argument should also be placed in the context of English law, which regarded the husband as the head of the family and the representative of it in its dealings with the world. Upon marriage, the woman lost her separate civil identity; it was assumed that she had voluntarily forsworn the claim to make choices at odds with those of her husband. In a powerful legal fiction, man and wife were understood to be one person; the married woman was the femme covert "covered" with her husband's legal identity for all practical purposes. Accordingly, the wife would have difficulty claiming injury that the husband did not also wish to recognize. See N. BASch, IN THE Eyes of THE LAW: WOMEN, Marriage AND Property IN NINETEENTH-CENTURY NEW YORK 17-21 (1982). 
her own lack of compassion for her husband's transgression. The court transformed the husband's hurt feelings, on the other hand, into an objective harm. This subjective/objective dichotomy resembles the gendered nature of the material/emotional dichotomy in the loss of consortium: the harm to the woman is conceived of as subjective; the same harm to the man is viewed as objective.

\section{FRIGHT FROM THE TURN OF THE CENTURY - A SyNOPSIS OF THE STANDARD LEGAL DOCTRINE}

The process of gender differentiation and gender disadvantage also exists in fright-based physical harm cases, although it is less visible than in the common law doctrine of consortium or criminal conversation. Contemporary casebooks and most legal commentators tell a degendered version of the legal doctrine. ${ }^{13}$ The standard account centers around three restrictive doctrines that have operated to limit recovery for fright-based injuries: the impact rule; the impact rule's modern descendant, the physical injury rule; and the bystander rule. The modern trend toward greater recovery has been accomplished by rejecting or relaxing these restrictive doctrines. Today, the impact rule has been discarded in virtually all jurisdictions and both the physical injury requirement and the bystander rule have been rejected in a significant number of states. ${ }^{14}$

The first doctrine - the impact rule - held that a plaintiff could not recover for any fright-based injury (whether classified as mental or physical) unless the plaintiff could point to some physical impact upon her person. Thus, for example, the impact rule would insulate from liability the defendant who was fortunate enough not to hit the plaintiff but whose negligent "near miss" caused the plaintiff to suffer nervous shock and a resulting miscarriage.

A common justification for the impact rule treated it as a corollary of the more general legal principle that limited recovery to material, as opposed to emotional, harms. The rule allowed courts to indulge in the fiction that an injury traceable to fright was only "parasitic" to damage stemming from physical impact; thus, the law was not really

13. See, eg., R. Epstein, C. Gregory \& H. Kalven, Cases and Materiais on Torts 1049-83 (4th ed. 1984); 3 M. FrankLin \& R. Rabin, Cases and Materials ON TORT LaW AND ALTERNATIVES 284-320 (4th ed. 1987); F. HARPER, F. JAMES \& O. GRAY, THE LAW OF Torts § 18.4, at 681-705 (2d ed. 1986); J. Henderson \& R. Pearson, The Torts Process 562-80 (2d ed. 1981); W. Keeton, D. DobBs, R. Keeton \& D. OWen, Prosser and Keeton ON THE LAW OF TORTS § 54, at 361-67 (5th ed. 1984); R. POSNER, TORT LAW: CASES AND Economic ANAlysis 603-10 (1982); W. Prosser, J. WAde \& V. Schwartz, CaSes aND MATERIALS ON TORTS 392-409 (8th ed. 1988).

14. See W. KeEton, D. DobBS, R. KeEton \& D. Owen, supra note 13, § 54, at 364-67. 
affording recovery for mental distress in its own right. This fiction was important doctrinally because such parasitic damage, even of the mental distress variety, was recoverable under well-established law. ${ }^{15}$ For example, a plaintiff who suffered traumatic bodily harm as the result of a physical impact could also recover for pain and suffering, despite the fact that pain and suffering might be regarded as a kind of emotional harm. This rationale for the impact rule, however, was completely undercut by cases where the physical impact was slight and it was clear that it was fright which produced the plaintiffs' injuries. Nevertheless, many American courts clung to the impact rule, allowing recoveries even where plaintiffs had experienced only very slight physical impacts. ${ }^{16}$

Oliver Wendell Holmes may have revitalized the impact rule by providing a new rationale "based upon a notion of what is practicable." 17 In a prominent case at the turn of the century, Justice Holmes found that the reason for the impact rule was to separate genuine from fraudulent claims, not to separate the physical from the mental. The requirement of an impact was said to function as some guarantee of genuineness. By shifting the rationale from the theoretical to the practical, Justice Holmes helped the impact rule to survive in a significant minority of the states until the 1960s.

The physical injury requirement is the modern descendant of the impact rule. It requires a plaintiff to demonstrate that her fright resulted in physical injury, rather than only mental distress. ${ }^{18}$ Like the impact rule, the physical injury rule requires visible or tangible proof of injury, but focuses on the injury itself, rather than on the manner in which the injury is brought about. Like its predecessor, the rule is said to guard against fraudulent claims, to limit recovery to serious injuries, and to discourage plaintiffs who suffer only transient harm from filing suit. Most jurisdictions have retained the requirement; only a

15. See id. at 362-63 (courts allow compensation for purely mental elements where defendant's negligence inflicts immediate physical injury); 1 T. STREET, FouNDATIONS OF LEGAL LIABILITY 470 (1906); Magruder, Mental and Emotional Disturbance in the Law of Torts, 49 HARV. L. REV. 1033, 1048-49 (1936).

16. See, e.g., Kentucky Traction \& Terminal Co. v. Roman's Guardian, 232 Ky. 285, 23 S.W.2d 272 (1929) (trifling burn); Porter v. Delaware, L. \& W. R.R., 73 N.J.L. 405,63 A. 860 (1906) (dust in eye); Zelinsky v. Chimics, 196 Pa. Super. 312, 175 A.2d 351, 354 (1961) ("any degree of physical impact, however slight," even jostling during car accident); see also STATE OF NEW YORK, LAW REVISION COMMISSION, ACT, RECOMMENDATION AND STUDY RELATINO TO LIABILITY FOR INJURIES RESULTING FROM FRIGHT OR SHOCK 49-61 (1936) (critiquing logic of slight impact requirement).

17. Homans v. Boston Elevated Ry. Co., 180 Mass. 456, 457, 62 N.E. 737, 737 (1902).

18. W. KeEton, D. DobBs, R. KeEton \& D. OWEN, supra note 13 , $\$ 54$, at $364-65$. 
minority of states, most notably California, have eliminated it. ${ }^{19}$ These more liberal states allow recovery for negligent infliction of serious mental distress, even if unaccompanied by physical manifestations or illness. ${ }^{20}$

The third limitation on recovery - the bystander rule - emerged as a principal impediment to recovery in a significant class of fright cases only after the impact rule had been repudiated. ${ }^{21}$ The bystander rule requires a plaintiff to prove that her injury is traceable to fear for her own personal safety, rather than fear or concern for the safety of another. This restriction gets its name because it prohibits witnesses to accidents from seeking recovery, thus limiting claims to primary accident victims. Many jurisdictions that were unable to tolerate the harsh results of the bystander rule have softened the rule to allow recovery to a plaintiff who feared for the safety of another person, if he or she were also physically imperiled by the defendant's conduct. The modified amended rule in these states became known as the "danger zone" rule - placing the emphasis on the physical location of the plaintiff rather than on the source of the mental distress.

The bystander or danger zone rules sometimes operated to prohibit relief in unusually shocking circumstances. One court, for example, applied the bystander rule to deny recovery to a mother of a newborn who witnessed a nurse negligently drop her baby onto the tiled floor of a hospital room, fracturing the baby's skull.22 Like the miscarriage cases, however, the bystander cases more often involved transportation-related injuries; typically, the plaintiff witnessed an automobile driver injure or kill a close family member. ${ }^{23}$

The tide against recovery turned in California with the now-celebrated case of Dillon v. Legg, ${ }^{24}$ decided in 1968. Dillon was a "typical" case in which a mother witnessed her child being run down by a negligent driver. The California Supreme Court rejected the stock arguments against bystander recovery and refused to treat the mother of

19. See Molien v. Kaiser Found. Hosps., 27 Cal. 3d 916, 616 P.2d 813, 167 Cal. Rptr. 831 (1980) (allowing cause of action for serious mental distress not resulting in bodily injury).

20. Rodrigues v. State, 52 Haw. 156, 171, 472 P.2d 509, 519 (1970) (courts are competent to administer claims of mental distress raised as independent grounds for recovery); Chappetta v. Bowman Transp., 415 So.2d 1019, 1022 (La. Ct. App. 1982) (no reason to distinguish between physical and independent emotional injuries); Bass v. Nooney Co., 646 S.W.2d 765, 772 (Mo. 1983) (allowing recovery for anxiety attack brought on when plaintiff was stuck in elevator).

21. See, e.g., Reed v. Moore, 156 Cal. App. 2d 43, 47, 319 P.2d 80, 82 (1957); Waube v. Warrington, 216 Wis. 603, 612-13, 258 N.W. 497, 500-01 (1935) (bystander rule prohibits recovery even though impact rule has been discarded).

22. Whetham v. Bismark Hosp., 197 N.W.2d 678 (N.D. 1972).

23. See W. KeEton, D. DoBBS, R. KeEton \& D. OWEN, supra note 13, § 54, at 366-67.

24. 68 Cal. 2d 728, 441 P.2d 912, 69 Cal. Rptr. 72 (1968). 
a child victim as just another bystander-witness to the accident. In place of the bystander limitation, the court substituted flexible, more plaintiff-oriented guidelines. ${ }^{25}$ The Dillon guidelines required courts to determine on a case-by-case basis whether an injury to a plaintiff was reasonably foreseeable. Although courts commonly apply tests of foreseeability in negligence cases, Dillon was exceptional because it authorized courts to take into account factors other than the plaintiff's physical proximity to the accident. Most significantly, the court recognized the existence of a family relationship between the plaintiff and the primary accident victim as a legally relevant fact. By shifting the focus from the foreseeability of impact to the foreseeability of fright, the court gave priority to claimants who could be expected to be shocked at witnessing the injury of a close family member.

Courts have been less willing to jettison the bystander rule than they were to reject the impact rule. While the equity of the bystander limitation is now rarely defended, many courts fear that the Dillon guidelines will not limit recovery to a sufficiently narrow class of plaintiffs. In these restrictive jurisdictions - most prominently New York - the danger zone rule represents the farthest boundary for granting recovery to those who witness accidents. ${ }^{26}$ Thus at present, recovery for a mother who witnesses her child's injury depends on the jurisdiction in which the accident occurs and the number of feet she happens to be from the site of the accident.

The history of the doctrine governing fright-based injury often bewilders students in first-year torts classes until the doctrine is described as evidence of the law's gradual evolution toward a more liberal, plaintiff-oriented system of recovery. The scheme becomes more comprehensible when students are told that the old law that virtually closed off recovery for fright-based injuries is gradually being replaced by a more flexible system that permits some classes of plaintiffs to recover, so long as they fall within the new set of boundaries established by the courts in the various states. Indeed, Archie Hefner, one of the lawyers for Margery Dillon, had been impressed by a simi-

25. The Dillon court instructed that the following three factors be taken into account in determining whether a defendant owed a plaintiff the duty not to act negligently:

(1) Whether plaintiff was located near the scene of the accident as contrasted with one who was a distance away from it.

(2) Whether the shock resulted from a direct emotional impact upon plaintiff from the sensory and contemporaneous observance of the accident, as contrasted with learning of the accident from others after its occurrence.

(3) Whether plaintiff and the victim were closely related, as contrasted with an absence of any relationship or the presence of only a distant relationship.

$68 \mathrm{Cal} .2 \mathrm{~d}$ at 740-42, 441 P.2d at 920, 69 Cal. Rptr. at 80.

26. See, e.g., Bovsun v. Samperi, 61 N.Y.2d 219, 461 N.E.2d 843, 473 N.Y.S.2d 357 (1984). 
lar prediction of liberalization offered by his torts professor at Hastings Law School, Arthur M. Cathcart. In 1946, Cathcart told his class that one day courts would allow recovery for emotional distress to a plaintiff who witnessed injury to another while standing outside the area of impact, and that the first classes of plaintiffs to recover would be parents and spouses. When Margery Dillon hired him, Hefner understood that he had been given an opportunity to convince the California Supreme Court to change the law of fright-based injury. He told Margery Dillon that she would become famous in the law. ${ }^{27}$

This evolutionary picture of the law focuses on a rebalancing of interests between the "class" of plaintiffs and the "class" of defendants in fright cases. This degendered narrative of the doctrinal rules, however, does not explain why this rebalancing has occurred nor whether this change in the law should be regarded as significant.

Contemporary torts casebooks generally convey the impression that the liberalization of rules governing fright-based injury has been a function of two external forces: the greater ability of medical experts and medical science to detect and understand mental disturbance, and the courts' greater reluctance to subsidize corporate defendants who inflict injury on individual plaintiffs. ${ }^{28}$ Neither the medical technology theory nor the corporate subsidy theory, however, fully captures the story of the legal treatment of fright-based injury. Degendered accounts of the evolution of the law governing fright-based injuries fail to account for the fact that maternal relationships are often at the center of these cases. They also fail to acknowledge the possibility that the "progression" of the law is related to changing societal views of women's roles. Further, these sex-neutral accounts of the law tend to obscure the gender significance of the basic legal hierarchy that places material property rights above relations and emotions. The liberalization of the law governing fright-based injuries may seem less impressive if we appreciate the asymmetry of the original rules - rules that treated emotional security as a qualitatively inferior interest and described even physical harm to women as emotionally based.

27. Telephone interview with Archie Hefner (Aug. 13, 1987).

28. See R. Epstein, C. Gregory \& H. Kalven, supra note 13, at 1049-83; M. FranKLiN \& R. RABIN, supra note 13, at 284-320; J. HENDERSON \& R. PEARSON, supra note 13, at 562-80; W. KeETON, D. DOBBS, R. KEETON \& D. OWEN, supra note 13, § 54, at 360; R. POSNER, supra note 13, at 603-10. One of the leading articles on the subsidy theory is Gregory, Trespass to Negligence to Absolute Liability, 37 VA. L. REv. 359, 368, 382 (1951). 


\section{Pregnant Plaintiffs: Early Application of the IMPACT RULE, 1888-1902}

A study of the early classic cases shows that gender has played an important role in the history of the cause of action for fright-based physical injury, and that degendered accounts of the law of fright are distorted and incomplete. From among the hundreds of reported decisions that have applied or discussed the impact rule, a handful of cases stand out as particularly significant, either because they were the leading statements in important jurisdictions or because they represented alternative approaches.

The story of the law's treatment of fright-based injury begins in the 1880 s, when courts in the British Empire and the United States first confronted claims of women who asserted that they suffered physical harm as a result of fright. Because the plaintiffs in each of the prominent early cases were women, a connection between women and fright was forged in the law of torts from the beginning. Several of these plaintiffs were pregnant at the time of the frightening occurrence and suffered miscarriages that they believed were caused by their fright. Many women seeking compensation for fright-based injury also alleged that they suffered from some form of hysterical disorder. Three distinct types of harms are embedded within these early suits for fright-based injuries: (1) physical injuries, including miscarriages, stillbirths, and hysteria-caused disabilities; (2) emotional distress, often necessitating long periods of bed rest; and (3) the relational harm of losing a potential child. In the late-nineteenth century, these harms were likely to be regarded as interrelated.

There are few clues as to why women began to seek compensation for fright-based injuries only in the late nineteenth century. The appearance of these claims may be linked to medical understandings of conditions known as neurasthenia and hysteria. In the 1870 s and 1880 s, pioneering neurologists, notably George Beard and S. Weir Mitchell, established a connection between mind and body, specifically that mental and emotional problems may produce physical manifestations. The recognition of neurasthenia, "a disease characterized by profound physical and mental exhaustion," 29 legitimated a category of disease that had previously been dismissed as hypochondria. This understanding rested heavily on the work of the great French physician

29. Sicherman, The Uses of a Diagnosis: Doctors, Patients, and Neurasthenia, in SICKNESS AND HeALTH IN AMERICA 23-24, 26, 32 (J. Leavitt \& R. Numbers 2d ed. 1985). Beard's most important treatise is G. BEARD, AMERICAN Nervousness: ITS Causes AND Consequences (1881); Mitchell's is perhaps S. Mitcheld, FAT AND Blood: AN ESSAY ON THE TreatMENT OF CERTAIN FormS OF NEURASTHENIA AND HYSTERIA (5th ed. 1888). 
Jean Martin Charcot, with whom Freud studied briefly. As Nathan G. Hale, Jr., has explained, Charcot taught that "[h]ysterical symptoms were real, not feigned. Hysterics were not malingerers . . .."30 In this context of a new understanding of psychosomatic illness, the diffuse disorder known as hysteria was medicalized. Women who suffered fright-based harm acquired a language that allowed them to articulate their experience as an injury. Thus, the social and medical forces that legitimated neurasthenia as a diagnosis in the late nineteenth century may also have sustained women in their perceptions that they were entitled to both medical and legal recognition for harms they experienced.

Despite these new understandings, the older perception that hysteria was a disorder traceable to the uterus and was therefore peculiar to women continued to persist both inside and outside the medical community. Medical definition of hysteria as an authentic illness was undercut by physicians' simultaneous suspicion that, as Carroll SmithRosenberg has argued, the hysterical woman was likely to be guilty of conscious malingering, "self-indulgence," and "moral delinquency." 31 Even S. Weir Mitchell, famous for his treatment of hysterical women, described them as "the pests of many households, who constitute the despair of physicians, and who furnish those annoying examples of despotic selfishness, which wreck the constitutions of nurses and devoted relatives, and in unconscious or half-conscious self-indulgence destroy the comfort of everyone about them."32 Therapy for hysteria reflected this distrust: it involved isolating the patient from all except the doctor, who then dominated the patient emotionally. ${ }^{33}$ In short, treatment could be punitive.

The triad of hysterical illness, fright, and injuries related to childbirth shared a close connection to the societal view of middle- and upper-class women as frail, dependent beings who were often unfit for their assigned role as childbearers and childraisers. ${ }^{34}$ When women

30. N. Hale, Freud and the Americans: The Beginnings of Psychoanalysis in THE UNITED STATES, 1876-1917, at 125 (1971).

31. C. SMith-Rosenberg, The Hysterical Woman: Sex Roles and Role Conflict in Nineteenth-Century America, in DisorderLy CONDUCT: VISIONS OF GENDER IN VICTORIAN AMERICA 197, 203-08 (1985).

32. Id. at 207 (quoting S. W. Mrtchell, Lectures on the Diseases of the Nervous SYSTEM, ESPECIALLY IN WOMEN 266 (2d ed. 1885)).

33. The most familiar description of the experience of the "rest cure" is Charlotte Perkins Gilman's story The Yellow Wallpaper in C. Gilman, The Charlotte Perkins Gilman READER 3 (1980).

34. A man's claim for fright-based injury during this period would have been much harder to fit into this medico-social framework. The critical tie to reproductive injury would be broken in the man's claim, not only because there would be no resulting miscarriage or stillbirth but also because hysterical injury would not be a likely diagnosis for a male patient. While the availabil- 
turned to the courts for redress of fright-based injury, these conflicting views surrounding hysteria reappeared. Confronted with these claims, most courts were unwilling to elevate hysterical illness - even if traceable as a matter of fact to negligence - to the level of a legally cognizable harm. The courts generally echoed the ambivalence and skepticism found in the medical profession and developed a doctrine of fright-based injury that allowed compensation for only a fraction of the physical injuries suffered.

The first notable case involving a claim of fright-based injury was an Australian case decided by the Privy Council in 1888. Victorian Railways Commissioners v. Coultas ${ }^{35}$ involved a near miss at a railroad crossing. The plaintiff, Mary Coultas, was riding in a buggy with her husband and brother. An employee of the defendant-railroad negligently signaled the buggy to cross and Mary Coultas feared that she and her companions would be killed by the fast-approaching train. Mary Coultas' husband managed to get the buggy across the track, so that the train passed close to the back of the buggy but did not touch it. Mary Coultas fainted into the arms of her brother and there was medical testimony to the effect that she suffered a severe nervous shock, a miscarriage, prolonged physical illness, and impaired memory and eyesight. ${ }^{36}$

Without reaching the question of whether impact was necessary to establish liability for fright-based injuries, the Privy Council denied recovery. The Council based its holding on the narrow ground that the damages were too remote, but listed three additional justifications for denying recovery. Although the opinion is quite terse, it contains virtually all of the basic arguments that would be enlisted in the service of defendants for the next one-hundred years.

The first argument against recovery - the remoteness argument - is somewhat difficult to understand, at least to the contemporary reader. The court merely asserted that Mary Coultas' fright was not to be expected in the "ordinary course of things." 37 This unadorned statement of "fact" seems counterintuitive. Even in 1888, many persons would presumably be frightened by a near collision with a locomotive. But the court seemed to think that Mary Coultas' injuries were more extensive than might reasonably be expected. At one point,

ity of neurasthenia as a diagnosis made men, as well as women, more free to confess to anxieties, insomnia, palpitations, impotence, and other nervous disorders, men still lived in a culture that severely inhibited them from publicly confessing weakness. Sicherman, supra note 29, at 26-28.

35. 13 App. Cas. 222 (P.C. 1888).

36. 13 App. Cas. at 223; see also Coultas v. Victorian Rys., 12 V.L.R. 895 (1886) (disclosing that plaintiff suffered a miscarriage).

37. 13 App. Cas. at 225. 
the court described her injuries as arising from "mere sudden terror unaccompanied by any actual physical injury." 38 Although the court did not explicitly classify Mary Coultas as a supersensitive person, the court's remoteness justification echoed the defense counsel's argument that "[a] mere nervous shock caused by fright of an impending event which never happens results from the constitution and circumstances of the individual." 39 The court's definition of remoteness did not reflect temporal or spatial distance between the defendant's negligence and Mary Coultas' injuries. Rather, it classified her injury as remote because of its judgment that a normal person would not suffer physical injuries as a result of such an incident. It therefore used "remote" to mean "abnormal" or "unusual."

This focus on the personal characteristics and response of the plaintiff introduced gender into the case in an unsubtle way. It was Mary Coultas who fainted and suffered the physical effects of nervous shock, not her brother or her husband, although they also were exposed to the same danger. Fright-based injury cases inevitably deal with a wide range of individual responses to danger. Whether under the rubric of remoteness or some other legal principle, courts will often make implicit judgments about the qualities of the person they choose as the standard against which to measure individual responses. ${ }^{40}$ Mary Coultas was too delicate to qualify as a "reasonable man" entitled to recover against a negligent defendant.

The three other reasons the court offered to justify its denial of recovery would be viewed today as administrative in nature. The Council expressed concern that allowing recovery in this type of case would (1) spawn too many lawsuits, (2) open "a wide field ... for imaginary claims," and (3) cause difficult problems of proof of causation. ${ }^{41}$ The concern here seems to be to assure that the law not provide compensation for nonexistent or trivial harm. This concern complements the court's reluctance to compensate the sensitive plaintiff - unworthy plaintiffs are denied recovery because they either overreact to incidents, lie about their injuries, or delude themselves into believing that the defendant's negligence was the source of their harm. Like the remoteness rationale, these administrative reasons for denying recovery may not be divorced from considerations of the

38. 13 App. Cas. at 225.

39. 13 App. Cas. at 222.

40. See Finley, A Break in the Silence: Including Women's Issues in a Torts Course, 1 YALE J.L. \& FEMINISM 41, 57-65 (1989) (critiquing of gender bias underlying reasonable person standard); see also Bender, $A$ Lawyer's Primer on Feminist Theory and Tort, 38 J. Legal Educ. 3, 20-25 (1988).

41. 13 App. Cas. at 225-26. 
plaintiff's gender. Because these rationales focus on the likely trustworthiness of the plaintiff and the probable justness of her claim, the identity of the typical plaintiff becomes the deciding factor.

The American counterpart to Mary Coultas was Annie Mitchell, the plaintiff in a famous 1896 New York case, Mitchell v. Rochester Railway. ${ }^{42}$ Mitchell is a particularly dramatic near-miss case. While Annie Mitchell was waiting to board one of the defendant's railway cars, a horse car driven by defendant's employee came so close to hitting her that "she stood between the horses' heads when they were stopped."43 Corroborated by medical testimony, Annie Mitchell claimed that her fright caused her to lose consciousness and suffer a miscarriage.

The New York court's reasons for denying recovery were very similar to those of the Privy Council in Coultas. ${ }^{44}$ In addition to the four arguments advanced in the earlier case, however, the New York court contended that it was "logical" to deny recovery for the physical effects of fright because fright alone was not a legally cognizable injury. ${ }^{45}$ This seemingly neutral doctrinal observation did not survive the scrutiny of the legal commentators of the day. Writing six years after Mitchell was decided, Professor Francis Bohlen chastised the court for failing to distinguish a fright-based injury case resulting in physical harm from a case that involved purely emotional harm. ${ }^{46}$ No logic required physical harm to be viewed as parasitic or subordinate to the fright. The legal question could be framed in a way that was more receptive to plaintiff's position, i.e., why should the law treat physical injury produced by fright less favorably than physical harm produced by any other causal mechanism?

In Spade v. Lynn \& Boston Railroad, ${ }^{47}$ decided one year after Mitchell, the Massachusetts Supreme Judicial Court reiterated and

42. 151 N.Y. 107,45 N.E. 35 (1896).

43. 151 N.Y. at 108,45 N.E. at 354.

44. The Mitchell court found it "quite obvious" that Annie Mitchell's miscarriage was "the result of an accidental or unusual combination of circumstances, which could not have been reasonably anticipated." 151 N.Y. at 110,45 N.E. at 355 . Thus, her miscarriage was "too remote" to warrant recovery, even if there were a genuine causal connection between the fright and her injury. Further, the court expressed concern that these types of cases "would naturally result in a flood of litigation," 151 N.Y. at 110, 45 N.E. at 354, in which plaintiffs would either feign injury or, even if sincere, would produce only a speculative connection between the fright experienced and the harm suffered.

45. 151 N.Y. at 110,45 N.E. at 354.

46. Bohlen, Right to Recover for Injury Resulting from Negligence Without Impact, 50 AM. L. REG. 141,172 (1902).

47. 168 Mass. 285,47 N.E. 88 (1897). The case was retried and a second jury verdict for the plaintiff was overruled by the appellate court. Spade v. Lynn \& Boston R.R., 172 Mass. 488, 52 N.E. 747 (1899). 
built upon the arguments presented in both Coultas and Mitchell. Margaret Spade was a passenger on the defendant's railway when the defendant's employees forcibly ejected two drunken passengers standing beside her. Although plaintiff was actually grazed by one of the ejected passengers as he "lurched" off the car, Margaret Spade admitted that it was the fear caused by the incident that produced her subsequent hysterical paralysis and other ailments. ${ }^{48}$

The Spade opinion is notable for its candor. The court did not rely on the pegs of remoteness or absence of proximate cause to deny recovery, but instead focused squarely on the relevant qualities of the plaintiff and defendant. The court believed that only "a timid or sensitive person" might suffer a physical injury because of fright. 49 The court's unwillingness to believe that a normal person would suffer physical harm from fright is much like that of its predecessors. But the court also went beyond prior cases to reach the normative conclusion that the law ought not to be structured to protect the interests of this group of unusually sensitive persons. The Massachusetts court openly expressed its concern that a ruling for the plaintiff would jeopardize "[n] ot only the transportation of passengers and the running of trains, but the general conduct of business and of the ordinary affairs of life." 50 In its view, the "logical vindication" of the impact rule was that it would be unreasonable to hold a "merely negligent" defendant to pay for even the real consequences of fright..$^{51}$

The image that emerges from Spade is one of a hypersensitive plaintiff whose claims pose a threat to business-as-usual. Even though ordinary tort principles allowed recovery only when the defendant was negligent and the plaintiff was free from contributory negligence, the Massachusetts court feared that the application of these ordinary principles in cases of fright-based injuries would impose a disproportionate liability on defendants. This sense of disproportion arose both from the court's view of plaintiff's injury as marginal and from its belief in the social importance of defendant's activity.

Justice Holmes incorporated the public policy aspects of Spade in a later Massachusetts case, Homans v. Boston Elevated Railway. ${ }^{52}$ In Homans, a woman experienced "a good deal of suffering of a hysteri-

48. Spade, 168 Mass. at 286,47 N.E. at 88 . It was in a later opinion, Homans v. Boston Elevated Ry., 180 Mass. 456, 457, 62 N.E. 737, 737 (1902), that Margaret Spade's condition was described as hysterical paralysis.

49. 168 Mass. at 288,47 N.E. at 88 .

50. 168 Mass. at 289,47 N.E. at 89 .

51. 168 Mass. at 290,47 N.E. at 89.

52. 180 Mass. 456,62 N.E. 737 (1902). 
cal nature" as a result of a nervous shock stemming from a subway collision..$^{53}$ Holmes treated the impact rule as the pragmatic accommodation of public policy interests - defendants would be held liable to sensitive plaintiffs only if the plaintiffs could guarantee the genuineness of their fright-based injury by showing "a substantial battery of the person," i.e., a non-negligible impact. ${ }^{54}$ In Homans, Holmes determined that recovery was justified because there was evidence that the plaintiff had been thrown against a seat in the collision. This nuance in the facts thus meant the difference between recovery and dismissal. Holmes was willing to tolerate the harsh, arbitrary character of the rule and to favor the interests of industry against the fragile plaintiff, so long as the court would not also have to adjudicate a claim for physical injury. If a plaintiff were already properly in court with a claim based on an injury stemming directly from the contemporaneous impact, Holmes wished to save the court the trouble of determining whether the shock came from the battery or from the fright. Thus, the plaintiff could find legal protection if her claim posed no additional burden on judicial administration. The impact rule thereby afforded fright-based injury only precarious and contingent protection: women who suffered from the effects of fright might be allowed recovery provided the all-important outside impact could be proven.

Just as the impact rule was being firmly established in many American jurisdictions, however, it lost favor in the courts of Great Britain. The most famous case allowing damages for fright-based injuries even in the absence of physical impact is Dulieu v. White \& Sons, ${ }^{55}$ decided in 1901. Again, the plaintiff was a pregnant woman, who claimed that her shock caused her to give birth prematurely to an "idiot" infant. The only significant fact distinguishing Dulieu from the earlier cases was the plaintiff's location at the time of the incident: rather than being on the street, the plaintiff was tending bar in her husband's public house when the defendant negligently charged his team of horses into the premises.

In a long, scholarly opinion, Judge Kennedy refused to follow Coultas and its American progeny and dispensed with the impact rule. He believed that fright could cause physical injuries and that such injuries were not too remote as a matter of law. His basic approach was to compare fright-based injuries to other types of transportationrelated injuries. He argued that in collision and "running-down" cases, plaintiffs were compensated for all injuries to their health, in- 
cluding not only those resulting as an immediate consequence of the impact, but also those resulting from the "sequelae" of the occurrence - the sum of the physical and emotional trauma ensuing from the incident. ${ }^{56}$ Moreover, in cases other than those involving fright-based injuries, the established rule was to impose liability on the defendant for all the damages actually inflicted, even if the plaintiff was of the "thin-skulled" sort who suffered a greater loss than would the average or normal individual. Kennedy reasoned that a pregnant woman who suffered a miscarriage or premature birth from fright should be treated no less favorably than the man with a thin skull. ${ }^{57}$ His legal attack on the remoteness justification for denying relief was simple, yet novel fright-caused injury was not qualitatively different from other kinds of physical injury and there was nothing so unusual about miscarriages or other pregnancy-related harms to warrant special legal treatment. As for the administrative grounds for denying relief - principally the fear of fictitious or unmeritorious claims - Kennedy expressed more faith than his predecessors in the court's ability to "get at the truth in this class of claim."58

Kennedy's opinion did not display any particular appreciation of gender. He did not, for example, stress the severity of the injury to the plaintiff or emphasize the fact that she was pregnant. Instead, his plaintiff orientation seemed to derive from his belief that nervous shock is a real harm not substantially different from other injuries for which the law grants compensation in tort.

The concurring opinion in Dulieu, by Judge Phillimore, also supported recovery but on a much narrower ground. Unlike Judge Kennedy, Phillimore followed the arguments expressed in Spade that public policy justified the refusal to protect "unfit" persons, including pregnant women, from the hazards of transportation when there was no collision. ${ }^{59}$ However, he concluded that whatever leeway was necessary to protect the day-to-day operations of railway companies and similar defendants ought not insulate them from liability for harms they caused to persons in their own homes. The pregnant plaintiff deserved compensation in this case because she was in her home, "where she had a right, and on some occasions a duty, to be."60 Gender thus found its way into Phillimore's opinion as relevant to delimiting the scope of the defendant's duty. Inside the home, pregnancy and

56. 2 K.B. at 678 (Kennedy, J.).

57. 2 K.B. at 679 (Kennedy, J.).

58. 2 K.B. at 681 (Kennedy, J.).

59. 2 K.B. at 684 (Phillimore, J., concurring).

60. 2 K.B. at 685 (Phillimore, J., concurring). 
its dangers would be safeguarded from external hazards, but a pregnant women might be required to bear the risks of machines and human negligence once she ventured outside.

These early impact-rule cases did not explicitly turn on the sex of the plaintiff; the legal rules that emerged from the opinions were worded neutrally. But the fright-based injuries themselves at issue in the classic cases were not gender-neutral. Miscarriage, premature birth, and "hysterical" disorders described women's health problems; the case law administering the impact rule was necessarily the law's administration of redress for gender-related harms. In other cases of negligently produced physical harms, formal legal doctrine required compensation for all proximately caused injuries. The law's treatment of fright-based harms was much less generous.

The early cases suggest that the vitality of the restrictive doctrine was related to the sex of the plaintiffs and the gender based nature of their injuries. Beyond the fact that the plaintiffs were women and frequently complained of gender-related harms, the gendered nature of this cause of action comes through by means of three legally significant judgments articulated by the courts.

First, there was the belief that only supersensitive or abnormally delicate persons could suffer physical harms from fright. The standard here seems to be male; it certainly is nonpregnant persons. The conventional wisdom of the time accepted the notion that miscarriages and other birth-related harms could stem from fright or nervous shock and that it was not abnormal for pregnant women to suffer such responses, at least if the stimuli were frightening enough. ${ }^{61}$ In gauging the normality of a person's internal response to danger, the courts either did not take the hazards posed to pregnant women into account, or they regarded them as so unique as to warrant special, less solicitous treatment. In the first edition of his famous treatise on torts, Wil-

61. See Morris v. L. \& W. R.R., 228 Pa. 198, 201, 77 A. 445 (1910) ("It is a matter not only of scientific but of common knowledge that miscarriages are often caused by fright or nervous shock....") This understanding faded only slowly. As late as 1932 one standard text observed: "Accidents which affect the mother frequently produce abortion: such as a fall ... a sudden and great fright and an overwhelming and prostrating emotion." E. DAVIS, CoMPLICATIONS of PREGNANCY 127 (1932). But other authorities had begun to question the older wisdom: "The emotions, fright, anger and grief, are not only rare but questionable causes of [spontaneous] abortion .... [One researcher] could attribute [spontaneous] abortion to the emotions in only $1.6 \%$ of his [cases]." Litzenberg, Spontaneous Abortion and Premature Labor, in 1 OBSTETRICs AND GYNECOLOGY 1084, 1094 (H. Curtis ed. 1934). By the 1970s, obstetricians believed that "most spontaneous abortions ... occur some time after death of the embryo or fetus" and, therefore, "[i]f abortion were caused by [psychic or physical] trauma, it would likely not be a very recent accident but an event that had occurred some weeks before." J. PRICHARD \& P. MACDONALD, Williams' on OBSTETRICs 591 (16th ed. 1980). Still it remained possible that a very small proportion - one out of 1000 - suffered spontaneous abortions caused by psychic shock. Id. 
liam Prosser remarked that "[i]t is not difficult to discover in the earlier opinions a distinctly masculine astonishment that any woman should ever be so silly as to allow herself to be frightened or shocked into a miscarriage."62

Second, there was a fear that allowing a cause of action for frightbased injury would open the courts to imaginary claims. Not only did the courts seem to distrust the legal system's ability to ferret out the weak claims; they seemed to distrust the potential claimants. Because miscarriages and stillbirths are empirically verifiable events, the distrust in this class of cases is hard to fathom. Difficult problems of proving causation could occur in individual cases, but such problems were not unique to miscarriage cases and might occur in cases involving other bodily disorders arising subsequently to a traumatic event. The fear of imaginary claims may have stemmed in part from a fear that women would be unreasonable in their assessment of the causes of pregnancy-related problems and would seek to place the blame for misfortune externally.

Third, the cases displayed a sympathy for the plight of corporate defendants exposed to claims by a potentially large class of persons. The attitude seemed to be that the infirm, the unfit, and the sensitive must take their chances when they venture outside their homes. The message to pregnant women was that the dangers of injury, and particularly of uncompensated injury, increased on the public streets. The structure of legal recovery reinforced the notion that women's proper sphere was domestic and that industry would not be compelled to accommodate women's interest in freedom of mobility, at least when they were pregnant. This assumption, taken together with the other two negative judgments, provided the policy arguments against affording compensation to women who suffered fright-based physical harm.

The theoretical support for denying recovery came from judicial placement of physical harm caused by fright in a separate legal category from physical harm caused by impact. This legal distinction transformed a recurring physical injury to women - fright-based miscarriages and other birth-related trauma - into a special type of nonphysical harm that the law would not recognize. The legal system is generally willing to assign legitimacy to harms viewed as arising from forces outside the body of the injured party. Difficulties occur when the harm seems to arise from within the body of the plaintiff. Women who suffer fright-based miscarriages experience a particular type of interference with physical integrity, an invasion that is often problem-

62. W. Prosser, HaNdBook on the LAW of Torts 55 (1st ed. 1941). 
atically described as injury from within. ${ }^{63}$ The legal response to this type of interference was to label the case one of emotional disturbance, thereby placing it at the margin of the law rather than at its center. In this way, the law's category of emotional harm was gendered as female. ${ }^{64}$ The history of this tort is also the history of women's tort law.

\section{Finding Gender in the Impact Rule: Pre-Realist COMMENTARY, 1902-1921}

In general, traditionalist legal scholars in the first two decades of the twentieth century were critical of the reasoning and most of the results of the early restrictive cases. Many were unconvinced that there were persuasive reasons for a wholesale denial of recovery for fright-based physical injuries. The liberal attitudes expressed reflected a faith in the ability of medical science to aid the law in this area, with little conscious focus on the gender-related nature of the tort beyond a recitation of the facts of the major cases.

The first widely cited American law review article on fright was written by Francis Bohlen, ${ }^{65}$ a University of Pennsylvania law professor who would later become the first Reporter for the Restatement of Torts. ${ }^{66}$ The major thesis of his 1902 article, which would be taken up by the courts when they wished to dismantle the impact rule, was that a fright-based physical injury case should be viewed as just another kind of physical injury case, rather than as an attempt to expand recovery to encompass purely mental suffering. ${ }^{67} \mathrm{By}$ viewing fright as the mechanism by which legally cognizable harm is produced, Bohlen undercut the argument for viewing these cases as conceptually distinct. Most importantly, he predicted no special difficulty with proof of causation, because of his belief that medical testimony could prove the causal connection "quite as accurately" in non-impact cases as in impact cases. ${ }^{68} \mathrm{He}$ did not display open mistrust of the credibility of

63. Robin West draws a distinction between a harm of "annihilation" and a harm of "invasion." "Annihilation" in traditional liberal legal theory is a violent threat external to the body. In contrast, the harm of "invasion," not as well recognized in law, is a violent threat emerging from inside the body, as, for example, with the fetus in an unwanted pregnancy. West, Jurisprudence and Gender, 55 U. CHI. L. REv. 1, $59-60$ (1988). Miscarriages induced by fright alone were considered harm from "within," despite the fact that an external stimuli prompted the internal reaction.

64. For a discussion of gender not only as "a constitutive element of social relationships" but also as "a primary way of signifying relationships of power," see Scott, Gender: A Useful Category of Historical Analysis, 91 AM. HisT. REV. 1053, 1069 (1986).

65. Bohlen, supra note 46.

66. RESTATEMENT OF TORTS xi (1934).

67. Bohlen, supra note 46 , at 172.

68. Id. 
pregnant women and apparently was not worried that this class of plaintiffs would falsely or mistakenly attribute the cause of their miscarriages or other birth-related traumas to the actions of defendants. ${ }^{69}$ Bohlen's response to the standard remoteness argument was equally straightforward: it was problematic to view pregnancy as extraordinary or unusual because there was always a certain number of pregnant women in every community. ${ }^{70}$ Bohlen's liberal position thus stemmed from an assessment that the logic of the early cases was deficient, coupled with a confidence that medical science could be relied upon to delimit the scope of legal liability. His argument was ultimately reflected in the position of the First Restatement of Torts, which repudiated the impact rule. ${ }^{71}$ For the next three decades, Bohlen's article would serve as the foundation for many of the traditional critiques of the impact rule.

Another leader of the Restatement movement - Herbert Goodrich - employed science, rather than legal argument, as his principal weapon against the impact rule. Goodrich's 1921 article 72 was unusual because it went beyond traditional case analysis to value scientific thinking over legal precedent in arguing for a broader scope of recovery. Goodrich cast his argument in Darwinian terms. ${ }^{73}$ Relying principally on two medical treatises for empirical support, ${ }^{74}$ his basic assumption was that fear, properly viewed, is not a "purely emotional thing."75 $\mathrm{He}$ variously described the physical manifestations of fear as putting the body in shape "for fight or flight," as "clearing the decks for action," and as putting the "whole human body on a war basis."76 He speculated that harmful physical effects from fear are produced when there is no opportunity "to put strong feeling into action."77 As

69. It is interesting to contrast Bohlen's liberal attitude toward recovery for fright-based physical injury with his views on the proper limits of workers' compensation. Bohlen argued against recovery under workers' compensation for occupational disease on the grounds that a workers' compensation scheme encompassing occupational disease could not fairly allocate risks among employers and would discourage employers from hiring older workers. Bohlen, $A$ Problem in the Drafting of Workmen's Compensation Acts, 25 HARv. L. REv. 328, 348 (1912). He also predicted that workers would either "fabricate" claims or would mistakenly, even though in good faith, attribute the disease to their work. $I d$. at 345 . This mistrust of workers is reminiscent of the mistrust the Victorian courts displayed for female plaintiffs in fright cases, a mistrust that Bohlen did not appear to share.

70. Bohlen, supra note 46 , at 154 n. 37 .

71. RESTATEMENT OF TORTS, supra note $66, \S 436$, at $1117-18$.

72. Goodrich, Emotional Disturbance as Legal Damage, 20 MiCH. L. REv. 495 (1922).

73. Id. at $498 \mathrm{n} .5$ (citing Darwin for an explanation of the physical symptoms of fright).

74. Id. at 498 n.6 (citing W. Cannon, Bodily Changes in Pain, Hunger, Fear and RAGE (1915) and G. CRILE, The ORIGIN AND NAtURE OF THE EMotions (1915)).

75. Id. at 499.

76. Id.

77. Id. at 502 . 
for the right of legal recovery, Goodrich argued simply that as long as we "can trace and can see" the physical effects of fright, the law ought to afford recovery. ${ }^{78}$

From a feminist perspective, the fascinating aspect of Goodrich's article is the masculine rhetoric in which he generally described human response to frightening situations. From his account of the physiological changes that occur in the face of fear, Goodrich encouraged the reader to believe that fear is something that happens to men. Goodrich compared "[t]onight's passenger in the luxurious Pullman car, awakened from slumber by the . . cries of the injured in a railroad wreck" to "his prehistoric ancestor, battling bare-handed for his very life with his enemies of the jungle."79 For examples to support his thesis, he referred to the reactions of soldiers, ${ }^{80}$ a urine test done on the players of the Harvard football team, ${ }^{81}$ and the responses of businessmen following a decline in the New York stock market. ${ }^{82}$ Finally, to make the point that some kinds of emotional stimuli are "reinvigorating" rather than debilitating, Goodrich claimed that "the tired business man guesses right when he chooses the excitement of a whirly-girly show, instead of going home to bed." 83

These images of combative, worldly men exposed to frightening or emotionally stimulating events contrast sharply with the image that emerged from the case law of the fragile, pregnant woman who suffers a miscarriage from nervous shock. The only instance in which Goodrich referred explicitly to a female subject was in a hypothetical case based loosely on the facts of Spade. ${ }^{84} \mathrm{He}$ posited that " $A$, in a condition of partial intoxication which slightly interferes with his locomotion, meets a woman on the sidewalk. He does nothing. But she becomes frightened at him, suffers a shock, subsequent miscarriage, nervous prostration, other ills ad lib."85 In analyzing his own hypothetical case, Goodrich assured the reader that because $A$ had not acted negligently, no recovery would be forthcoming regardless of the injuries sustained. He then generalized that given the requirement of proof of negligence, "there seems slight danger that defendants will be placed at the mercy of the hysterical, the morbid, or the emotionally

\footnotetext{
78. Id. at 503.

79. Id. at 499.

80. Id. at 500 .

81. Id. at 502 .

82. Id. at 503 .

83. Id. at 502 .

84. Spade v. Lynn \& B. R.R., 168 Mass. 285, 47 N.E. 88 (1897).

85. Goodrich, supra note 72 , at 506.
} 
unbalanced."86

Goodrich's association of women with unreasonable emotional response is reminiscent of the arguments advanced in support of the impact rule. ${ }^{87}$ The interesting feature of the article, however, is that Goodrich generally supported recovery for fright-based injury, at least when the injury was conceived of as happening to normal men. The distrust of claimants surfaced when the injury was feminized and did not fit as well into Goodrich's masculinized account of the human response to fear.

\section{Frightened Mothers: The Legal Origins OF THE BYSTANDER RULE, 1923-1935}

In jurisdictions where the impact rule was in force, the question of whether recovery could be granted to witnesses to accidents did not need to be addressed. With the lifting or softening of the impact limitation, however, plaintiffs other than the primary accident victims were able to bring suit and the courts were forced to consider whether physical injury produced by fright at witnessing the fate of another should be actionable. Like the near-miss cases before them, the early bystander cases involved claims of women. The near-miss cases, however, frequently involved pregnancy-related injuries and thus were linked to women in a biological sense. The relationship of women to the bystander cases was more obviously social in nature, rather than biological. Mothers tended to care for young children and to suffer nervous shock at the injury of their children. The recurring claims of mothers suing as witnesses to the injury of their children may also be a function of an assessment by attorneys that mothers would make particularly sympathetic plaintiffs and would increase the chances of prevailing in this legally difficult cause of action.

The early precedents generally denied recovery if the fright causing the injury were produced by concern for another. This bright-line limitation had the advantage of limiting the class of plaintiffs to those who were close enough to the dangerous instrumentality to be physically endangered themselves. It had the significant disadvantage, however, of discounting intimate family relationships, because the only legally actionable fright was individually based.

The legal origin of the bystander rule stems from a dictum in the English case of Dulieu v. White \& Sons ${ }^{88}$ that repudiated the impact

86. Id. at 507.

87. See supra notes 61-63 and accompanying text.

88. 2 K.B. 669 (1901); see supra notes 55-60 and accompanying text. 
limitation. In speculating on the legal effect of lifting the impact requirement, Judge Kennedy stressed that he was not endorsing recovery in all cases of fright-based physical harm. He claimed that the plaintiff must prove that "[t]he shock, where it operates through the mind, must be a shock which arises from a reasonable fear of immediate personal injury to oneself." 89 Kennedy's opinion did not elaborate on the legal or policy bases of the bystander rule beyond suggesting that a defendant would owe no duty to a plaintiff who feared injury to a third party, because injury to such plaintiffs was too remote or unforeseeable.

In the United States, the Dulieu dictum met with widespread approval.90 The objections to recovery closely tracked those found in the impact-rule cases. From a doctrinal perspective, the bystander issue represented round two in the larger controversy over legal recognition of fright-based harms. A typical case arose in Wisconsin in 1935 when Susie Waube looked outside the window of her home and saw her daughter struck and killed by a negligent driver. ${ }^{91}$ Susie Waube became "extremely hysterical, sick and prostrated"92 and died less than a month later. Her husband brought a survival action to claim the recovery to which his wife would have been entitled had she lived. The Wisconsin Supreme Court dismissed the complaint, concluding that the defendant owed no duty to protect Susie Waube from harm.

The court's reasons for denying recovery echoed those advanced a generation earlier in the impact rule cases. ${ }^{93}$ As in the Spade ${ }^{94}$ case, the court candidly admitted that logic would provide no answer to the legal question posed and that " $[t]$ he answer must be reached by balancing the social interests involved in order to ascertain how far defendant's duty and plaintiff's right may justly and expediently be

\footnotetext{
89. 2 K.B. at 675.
}

90. The commentary to the Second Restatement of Torts indicated that, after 1930, the cases were opposed to liability toward "bystanders." The only support for liability in bystander cases came from three decisions in intermediate courts decided prior to 1915. RESTATEMENT (SECOND) OF TORTS $\S 313$, note to Institute (Tent. Draft No. 5, 1960).

91. Waube v. Warrington, 216 Wis. 603, 603-04, 258 N.W. 497, 497 (1935).

92. 216 Wis. at 604,258 N.W. at 497.

93. See supra notes $37-41,44$, and accompanying text. The twin concerns of disproportionate liability and encouragement of fraudulent claims surfaced again. Like the Massachusetts court in Spade v. Lynn \& B. R.R., 168 Mass. 285, 47 N.E. 88 (1897), the Wisconsin court believed that imposing liability in bystander cases would put an "unreasonable burden" on users of the highway, but gave no hint as to why the interests of the mother of the victim should be subordinated to the interests of users of the highway. Nor did the court indicate why this class of claims posed a different or greater incentive to fabrication than other fright-based claims, which were now allowed in Wisconsin, one of the growing number of jurisdictions where the impact rule had been rejected. Waube, 216 Wis. at 613,258 N.W. at 501.

94. Spade v. Lynn \& B. R.R., 168 Mass. 285, 47 N.E. 88 (1897). 
extended."95

The court began its analysis by characterizing Susie Waube's injuries as so "unusual or extraordinary" that they would not be expected by a negligent driver as a likely consequence of an accident. ${ }^{96}$ The court did not specify what feature of the accident was so unusual the presence of the victim's mother at the accident site, or the mother's severe response to the killing of her child. As countless commentators later pointed out, ${ }^{97}$ neither the mother's presence nor her reaction seems unusual at all. Mothers often tend to supervise young children and the mother-child relationship is emotionally close. As with the remoteness argument in the impact-rule cases, the unforeseeability argument in the bystander cases is probably best understood as a proxy for some other concern. It is possible that the courts regarded fright-caused physical injury as an overreaction to the death of another, a reaction that would not occur in a normal individual. The reasonableness of this assessment, however, hinges on whether the court regarded the plaintiff as a "mere bystander" or as a mother.

The Waube court's weightiest reason for denying liability was its concern with finding a clear-cut "stopping place" for liability in the bystander context. ${ }^{98}$ Various classes of persons might suffer mental distress as a result of witnessing injury to another: parents, spouses, other relatives, friends, and even strangers who witness the accident. Moreover, the number of potential plaintiffs could increase considerably if the law chose to compensate those persons who were not present at the scene of the accident but who suffered distress when they learned of it. This specter of greatly enhanced liability perhaps was exaggerated, particularly because all plaintiffs would then have been required to prove that they also suffered physical harm as a consequence of their distress. Nevertheless, the bystander cases clearly posed a multiple liability problem insofar as defendants would face potential liability both to the primary accident victim and to any witnesses. The ultimate scope of a defendant's liability might then depend on the court's view of the significance of the personal relationship between the witness and the primary accident victim. ${ }^{99}$

95. Waube, 216 Wis. at 613,258 N.W. at 501 .

96. 216 Wis. at 613,258 N.W. at 501.

97. See, e.g., RESTATEMENT (SECOND) OF ToRTS, supra note 90, at 10; J. Fleming, AN INTRODUCtion to the LAW OF TORTS 53 (1967); W. Prosser, HaNdBoOK ON THE LAW OF TORTS $\$ 37$, at 181 (2d ed. 1955).

98. 216 Wis. at 613,258 N.W. at 501 .

99. Judicial creation of a hierarchy of relationships was not unprecedented in tort law. The courts had long restricted claims for loss of consortium to husbands who lost the services of their wives as a result of a defendant's negligence. See W. MALONE, TORTS IN A NuTSHELL: INJURIES TO FAMILY, SocIal AND TRADE RELATIONS § 3-1, at 56-57 (1979). Under various stat- 
The maternal relationship emerged as a decisive factor in the 1925 English case of Hambrook v. Stokes Brothers, ${ }^{100}$ a rare case permitting recovery to a mother whose child was severely injured in a traffic accident. Mrs. Hambrook had just parted from her children on their route to school when she saw a runaway lorry careening down the hill in the direction of her children. When she learned from bystanders that a little girl had been struck and taken away, she sustained a nervous shock and a severe hemorrhage. Two and a half months later, she suffered a stillbirth and died shortly thereafter.

The court refused to follow the Dulieu ${ }^{101}$ dictum, and relied instead on its perception of the quality of the mother-child relationship as a justification for recovery. The requirement that plaintiff prove fear for herself as opposed to fear for another struck the court as unacceptable when the "bystander" was the victim's mother. To demonstrate the injustice of the bystander limitation, one judge hypothesized the following scenario:

Assume two mothers crossing the street at the same time when this lorry comes thundering down, each holding a small child by the hand. One mother is courageous and devoted to her child. She is terrified, but thinks only of the damage to the child, and not at all about herself. The other woman is timid and lacking in the motherly instinct. She also is terrified, but thinks only of the damage to herself and not at all about her child. The health of both mothers is seriously affected by the mental shock occasioned by the fright. Can any real distinction be drawn between the two cases? Will the law recognize a cause of action in the case of the less deserving mother, and none in the case of the more deserving one? Does the law say that the defendant ought reasonably to have anticipated the non-natural feeling of the timid mother, and not the natural feeling of the courageous mother? I think not. ${ }^{102}$

By thus associating fear for another with maternal instinct, the court explicitly feminized this species of tort claim. The court restated the question as a choice between validating the maternal instinct by permitting recovery or following a "discreditable" system of jurisprudence that rewarded nonmaternal mothers who valued themselves above their children. ${ }^{103}$

Today Hambrook may appear sexist because of its acceptance of unselfishness as the marker of natural motherhood. It is no longer

utes, wrongful death recovery had generally been restricted to spouses or children of the deceased. Id., $\S 2-4$, at 25-29. However, the courts tended not to draw these relational lines when it was emotional stress, rather than relational harm, that was the basis of plaintiffs claim. 100. 1 K.B. 141 (1925).

101. Dulieu v. White \& Sons, 2 K.B. 669 (1901); see supra notes $88-89$ and accompanying text.

102. 1 K.B. at 151 (Bankes, L.J.).

103. 1 K.B. at 157 (Atkin, L.J.). 
assumed that mothers are naturally or biologically courageous. Nor does it seem particularly courageous or desirable to forget about one's own personal safety in a dangerous situation. But what is striking about the Hambrook analysis is that it fashioned the rule of the case with women, and the particular plaintiff, uppermost in mind. In contrast to the cases denying recovery, the court did not characterize the injury as unusual or remote, in part because of its view that mothers would naturally worry about their children and suffer fright at their peril. The court expanded the objectivity of the law to encompass the reality of a familial relationship. By placing a high value on motherhood, the court created an adequate counterweight to the fear of disproportionate liability. Hambrook indicates that courts may sometimes be gender-conscious in favor of women. It would be almost fifty years, however, before the Hambrook arguments would prove powerful enough to turn the tide in favor of recovery in the United States.

\section{The Realist Perspective: Leon Green Dissects the TRADITION, 1933}

By the time Professor Leon Green tackled the fright cases in his 1933 article in the Illinois Law Review, ${ }^{104}$ there was a sizable body of reported decisions treating fright-based injuries. Green dissected this tradition using a new and distinctive approach - legal realism. Green was a major figure in the realist movement. When in $1931 \mathrm{Karl}$ Llewellyn listed the nation's leading legal realists, Leon Green was on the list - a list that also included William O. Douglas, Charles Clark, and Jerome Frank. ${ }^{105}$ Green's work on fright and his more general articles on negligence law ${ }^{106}$ were very infiuential. Only William Prosser, and perhaps a few others, had comparable reputations as torts scholars. ${ }^{107}$

Although Green was always skeptical of labels and usually took the position that he was simply being pragmatic, his 1933 article on the fright cases displayed the characteristic methods that were already

104. Green, "Fright" Cases, 27 U. ILL. L. REv. 761 (1933). Green published a second part to this article, Green, "Fright Cases," 27 U. ILL. L. REv. 873 (1933), that discusses fright-based harms deriving from intentional torts. Since our analysis deals with harms deriving from negligence, we have limited our discussion to Green's first article.

105. Llewellyn, Some Realism About Realism - Responding to Dean Pound, 44 Harv. L. REV. 1222, 1226 n.18 (1931).

106. Green's major articles are collected in L. GREEN, THE LITIGATION Process IN TORT LAW (1965). 1978).

107. See generally Robertson, The Legal Philosophy of Leon Green, 56 TExas L. REv. 393 
being associated with the new realist school of legal thought. ${ }^{108}$ Realists suspected that the rhetoric of precedent and tradition had been a vehicle for mystifying convenient political choices. The realists believed that the best basis for legal truth was knowledge of facts; they were skeptical of legal principle as a guide to the understanding of historical reality. Their skepticism was founded in part on the technological changes in publishing court decisions that had transformed the profession in the first third of the century: the inundation of reported cases from the state supreme courts and the federal circuits made it increasingly clear that actual decisions reflected idiosyncrasy and contradiction quite as much as they did legal principle. More importantly, perhaps, Green's generation of intellectuals - not only in the law but in the social sciences, humanities, and arts - were impelled by the faith that a science of human behavior could be developed. Not unlike the documentary photographers whose work resonated through the 1930s, or the WPA interviewers who collected the autobiographies of thousands of former slaves, the legal realists were suspicious of freefloating "natural laws," believing rather that sound decisions would emerge only after all the facts had been collected.109

Green shared the realist suspicion of legal principle, including the principle that the law afforded no remedy for fright-based physical injury. He claimed that "[n]ine times out of ten [legal principles] are far broader than the cases from which they are deduced, and thereby are highly deceptive."110

Green's major contribution to the scholarship on fright was his discovery of cases neglected by others and his unwillingness to accept the old conceptual framework as the starting point for discussion. At the time Green was writing, the standard critique of the impact rule had been offered by Bohlen, who had argued that fright causing physical injury should be actionable regardless of the presence of impact. ${ }^{111}$ Green was not interested in debating the logical merits of the impact rule. He preferred to group the cases around factual similarities or situation types, creating three new categories: derailment, passenger, and general traffic. ${ }^{112}$

Green's article suggested that the outcomes in fright-based injury

108. An insightful discussion of the characteristics of the diverse group known as the legal realists is contained in Singer, Legal Realism Now, 76 CALIF. L. Rev. 465 (1988).

109. See Purcell, American Jurisprudence between the Wars: Legal Realism and the Crisis of Democratic Theory, 75 AM. HIST. REV. 424 (1969).

110. Green, supra note 104, at 765 .

111. See supra notes $65-71$ and accompanying text.

112. Green, supra note 104 , at 763, 768, 775. 
cases were more likely to be influenced by contextual differences than by the presence or absence of physical impact. Green maintained that it was easier to assign responsibility to defendants in passenger or derailment cases than in general traffic cases. In general traffic cases, the courts were confronted with "infinite" problems created when "the pedestrian, the adjoining dweller, the operators of horse-drawn vehicles, street cars, railroads, and automobiles, together with their occupants, are subjected to risks." 113

In recategorizing the cases, Green attempted to be exhaustive. $\mathrm{He}$ considered not only the prominent decisions but presumably all of the reported fright cases. ${ }^{114}$ The picture that emerged from Green's dissection of these cases is a complicated one. No single factor or set of factors would explain the results in all the cases, although Green's analysis yielded a laundry list of possibly important factors. Green's major point seems to be that there never was a uniformity of results in this area; he also maintained that uniformity would not be desirable. ${ }^{115}$

Green occasionally appeared to be an apologist for the results of the cases, principally because he treated each decision as a social fact; he did not pass explicit moral judgment or assess the wisdom of social policy. Ironically, Green's radical methodology was used to defend the status quo in this area of tort law - Green's work later would be cited by conservative judges seeking a new rationalization for restrictive legal precedent limiting recovery. ${ }^{116}$ Green's position illustrates what Joseph Singer calls the ambivalence of many realist scholars. ${ }^{117}$ As a realist, Green derided conceptual thinking and the notion that legal results were preordained and separated from social reality. But Green seemed to believe that paying close attention to the facts would provide an explanation of results, even if precise predictions were impossible. Green did not appreciate fully that the scholar or judge must actively choose which facts are pertinent. The situation-types Green selected described his own perception of the social reality of fright

113. $I d$. at 768.

114. For example, Green unearthed a very early derailment case from Illinois that was far less hostile to recovery than later cases would suggest. Id. at $763 \mathrm{n} .14$ (citing Chicago \& N.W. Ry. Co v. Hunerberg, 16 Ill. App. 387 (1885)).

115. Id. at 762 .

116. For example, Green is cited in two notable cases denying recovery to mothers who witnessed their children's injury: Waube v. Warrington, 216 Wis. $603,606,258$ N.W. 497, 498 (1935); Amaya v. Home Ice, Fuel \& Supply Co., 59 Cal. 2d 295, 308-09, 379 P.2d 513, 520-21, 29 Cal. Rptr. 33, 40-41 (1963) (en banc); see also supra notes 91-99 and accompanying text (discussing Waube), and infra note 177 and accompanying text (discussing Amaya).

117. Singer, supra note 108 , at 502-03. 
cases; as a realist writing in the 1930s, he did not perceive that these fright cases might entail multiple social realities.

One of the few generalizations in which Green indulged was that courts in the early 1930 s were becoming more liberal in granting recovery, even in states that clung to the impact rule. He speculated that the change was a product of two social forces: the growing number of serious traffic injuries in the age of the automobile and the "more substantial" scientific basis for proving harm through fear. ${ }^{118}$

Despite Green's realist penchant for fact-sensitivity, he did not analyze the significance of gender as a factor influencing judgment. In the very first paragraph of his fright article, Green made the point that some courts had mistrusted claims of fright-based injuries. He then made a significant observation about the marginalization of this type of lawsuit: 'Their labels as 'fright' or 'mental suffering' cases signify the distrust with which they were at first, and still are, regarded by some courts. With few exceptions, recoveries have been restricted to women, and for most part, pregnant women."119 That is all Green had to say about gender. His single observation suggests that the fright cause of action is marginal to the law of torts and perhaps that only female plaintiffs stand a good chance of prevailing.

Green's observation about the gender of the plaintiffs in fright cases was not inaccurate, although it can be misleading. Green cited forty negligence cases in which fright was alleged to have caused the plaintiff's injury. In thirty-five of these cases the person suffering fright-based injury was a woman; only five cases involved men suing for the effects of fright. But neither men nor women fared very well in the courts. Of the women, only fourteen won their suits; of the men, only two were successful. 120 The significant datum is not that women recovered in more lawsuits than men, because they also lost more suits. The significant fact is that women tended to bring this type of lawsuit far more often than did men. Green was correct in thinking of fright-based injury as a woman-dominated claim, but his implication that the claims of women were favored by the courts was unsupported by the cases he cited.

Green's assertion that recoveries were restricted to women was reiterated by William Prosser in three editions of his famous treatise on

118. Green, supra note 104, at 772.

119. Id. at 761 .

120. This count of 40 cases includes only negligence cases in which the injury was produced principally by fright, rather than by physical impact. In his article, Green cited 87 cases of various types, including intentional torts, distress due to mishandled corpses, and libel. Overall, in the cited cases there were 62 female plaintiffs and 25 male plaintiffs. Women won their suits in 37 cases ( $58 \%$ success rate); men won in 11 cases ( $44 \%$ success rate). 
torts, the first published in 1941. Prosser noted that fright-based physical injury cases so frequently involved miscarriages "that [miscarriage] has come to typify them."121 By 1964, however, Prosser described Green's assertion as "something of an overstatement" and defensively asserted that "[a]lthough miscarriages are still plentiful, there is also a good supply of cases of heart attacks, and the like, occurring to mere males."122 Both Green and Prosser created the impression that women not only dominated the tort but that "mere" men might have a harder time recovering. But there is no reliable empirical data suggesting that the success rate for women was actually substantially higher in this type of case than it was for men.

Most significantly, if it is generally difficult for plaintiffs of either gender to win fright-based injury cases, the law might be said to be structurally biased against the class of plaintiffs who bring such suits. The analogy here would be to the structural bias that exists in the work force in the pay rates of men and women workers. As the comparable worth debate has made clear, ${ }^{123}$ a large portion of the gender pay gap is attributable to the fact that most women wage workers are employed in low-paying "female" jobs. Low compensation for women's jobs may appear gender neutral because the few men who work at such jobs are also disadvantaged. The structural bias, however, derives from the undervaluation of jobs dominated by women, regardless of the equal treatment of individual workers within each job category. For such a structural bias to exist in the law of fright-based injury, two propositions must obtain: recovery for fright-based injuries must be disfavored in law (as compared to other tort claims) and women must be more likely to sue for such disfavored claims. Green and other legal commentators of this time seemed to have assumed both propositions to be true. They did not, however, regard this structural bias as discrimination against women.

Like other liberal intellectuals of his generation, Green was moved by the faith that documentation of social reality was essential to understanding and to reform. Contemporary feminism shares a similiar distrust of abstractions and a preference for the concrete. Green's work is liberating for feminists because he was not afraid to challenge the legal categories and to show how the law is infinitely malleable and

121. W. Prosser, supra note $62, \S 34$, at $213-14$ \& n.55; W. PROSSER, supra note $97, \S 37$, at 178 \& n.4 (2d ed. 1955); W. Prosser, HANDBOOK OF THE LAW OF TORTS $\S 55$, at $350 \&$ n.80 (3d ed. 1964) [hereinafter W. Prosser, TORTS].

122. W. Prosser, TORTS, supra note 121 , $\$ 55$, at 350 n. 80 .

123. For a discussion of the growing body of scholarship on comparable worth, see H. KAY, SEX-BASEd DisCRIMINATION 712-18 (3d ed. 1988). 
untidy. Yet in 1933 Green did not possess a feminist's inclination to trace the implications of his assertion about the gender of the plaintiffs in fright cases. His realist approach remained indifferent to questions of sexual equality.

\section{The Freudian Perspective: Dr. Smith Opposes RECOVERY, 1944}

The longest and one of the most frequently cited law review articles on fright-based injury is Dr. Hubert Winston Smith's Relation of Emotions to Injury and Disease: Legal Liability for Psychic Stimuli, ${ }^{124}$ written during World War II. The article was cited, for example, in the 1963 opinion in Amaya v. Home Ice, Fuel \& Supply Co., ${ }^{125}$ the California case that was the immediate antecedent of Dillon v. Legg. ${ }^{126}$ Smith was also relied upon heavily in the most recent edition of Harper, James, and Gray's well-known treatise on torts. ${ }^{127}$ Smith was well-credentialed in both law and medicine: he received his law degree from Harvard in 1930 and his medical degree from Harvard in 1941. Commissioned a lieutenant in the Medical Corps of the Naval Reserve, Smith spent the war years as an "Associate in Medical-Legal Research" in Harvard's Law and Medical Schools. ${ }^{128}$

The distinctive feature of Smith's article was his effort to offer a review of fright-based injury cases that was informed by modern medical scholarship. Smith purported to examine 301 cases in which plaintiffs claimed psychic injury. His subject matter was broader than fright-based physical injury: he included within his category of nervous shock some cases in which there was no allegation of physical injury, including the famous Lynch v. Knight slander case discussed earlier. ${ }^{129}$

More than any other legal commentator, Smith expressed awareness of gender in his analysis of the case law of fright. His summaries of the early cases showed that women predominated as plaintiffs and that the injuries complained of were often sex-based, especially in that

124. 30 VA. L. REv. 193 (1944). The volume also contains a companion article on traumatic neurosis, jointly authored by Dr. Smith and Harry C. Solomon, Traumatic Neuroses in Court, 30 VA. L. REV. 87 (1943).

125. 59 Cal. 2d 295, 311, 379 P.2d 513, 523, 29 Cal. Rptr. 33, 43 (1963).

126. 68 Cal. 2d 728, 441 P.2d 912, 69 Cal. Rptr. 72 (1968) (en banc); see infra notes 183-99 and accompanying text.

127. F. HARPER, F. JAMES \& O. GRAY, supra note 13, § 18.4, at nn.1, 5, 9, 12, 18, 26, 27, 36.

128. 1965 DiRECTORY OF LAW TEACHERS IN AMERICAN BAR ASSOCIATION LAW SCHOOLS 318; see also Smith, supra note 124, at 193.

129. Smith, supra note 124, at 313 (table A20); see also supra notes 9-12 and accompanying text (discussing Lynch v. Knight, IX H.L. Cas. 576, 11 Eng. Rep. 854 (1861)). 
so many cases involved pregnancy and miscarriage. In summing up the legal state of affairs in the early twentieth century, Smith recognized the courts' implicit assumption "that normal persons do not suffer injury from fright." $130 \mathrm{He}$ did not criticize the courts for treating women's harms as abnormal or for failing to compensate women for recurring injuries in their lives. Rather, Smith concluded his article by entreating the courts to refuse recovery - in the name of modern medicine.

As a physician, Smith was interested in making the point that the direction of modern medicine, and especially of modern psychiatry, had established as "a scientific fact that adequate psychic stimuli can produce a varying degree of disability in a normal person."131 This disability might appear immediately and with dramatic force, as in miscarriage. But the new field of psychosomatic medicine enabled the physician to diagnose more subtle presentations of psychic disability, not all of which appeared overnight and some of which required "usually a long bombardment with emotional stimuli" over a period of time. ${ }^{132}$ Smith had in mind disorders such as asthma, angina, hypertension, colitis, peptic ulcers, gastritis, anorexia nervosa, and psoriasis. 133

Smith's understanding of the multiple medical consequences of fright led him to search for a line behind which to confine legal liability. Like his Victorian predecessors, he chose to limit recovery to "normal" individuals - but Smith deployed Freudian-sounding arguments to discredit claims of women (and some men) who did not measure up to his conception of normality. In Smith's view, normal people generally suffered only "temporary upset or fleeting illness" from the nervous shock produced by psychic stimuli. More serious consequences usually meant that the plaintiff was "idiosyncratic" Smith's term for abnormal. Smith maintained: "The relationship of emotional stimuli to grave physical injury and to diagnosable disease seems to involve a weak link previously present. The mechanism of injury here usually involves aggravation of a preexisting impairment with the factor of individual idiosyncrasy or susceptibility playing the dominant role." $" 134$

Smith's medicalized notions of normality disadvantaged women. He believed that it was proper to classify pregnancy as "a temporary

130. Smith, supra note 124, at 210.

131. Id.

132. Id. at 217.

133. Id. at 217-20.

134. Id. at 225-26. 
idiosyncrasy"135 and that "[a]n actor should not be required to assume that every female in his path is about to become a mother." $136 \mathrm{He}$ asserted that the Coultas ${ }^{137}$ court was "shrewd" in denying Mary Coultas recovery for her miscarriage because "injury through emotional stimuli in civilian life is a rare result usually due to idiosyncrasy."138 With regard to injuries sustained by mothers or other close relatives who witnessed their child's death or injury, Smith characterized the plaintiffs' susceptibility to shock as "similar to an idiosyncrasy."139 Although Smith did not endorse a blanket rule against recovery in all "bystander" cases, his notion of the occasions in which defendants could fairly be held to anticipate and guard against these "special" risks of harm was quite restricted. ${ }^{140}$

Beyond these paradigm cases of nervous shock, Smith also believed that far more women than men were likely to develop traumatic neuroses as a result of psychic stimuli. Smith was extremely hostile to this class of plaintiffs and claimed that a patient suffering from a traumatic neurosis was "never as badly off as he appear[ed]."141 In a companion article on traumatic neurosis, Smith theorized about the origin of traumatic neurosis, with sex role stereotypes at the core of his "analysis":

Males venture into places of peril as much as females and so are as frequently exposed to [trivial impacts or psychic stimuli]. But the male is usually the breadwinner; his thoughts are distracted from his experience by the tasks of his job, and further, he has much to lose and little to gain by developing a neurosis. The female is usually at home, has more time to ponder upon the experience, and more to gain and less to lose from developing symptoms. The independent post-accident psychological forces conducing to neurosis are apt to be more potent in her case..$^{142}$

Smith conjured up the image of a neurotic woman who, with the

135. Id. at 296. Smith described pregnancy in the following contradictory terms:

Pregnancy is a normal biological state for a young woman, yet miscarriage could not occur without it. For that reason it may be proper to classify pregnancy as a temporary idiosyncrasy as it makes the expectant mother susceptible to an injury which the non-pregnant woman could not sustain. Id.

136. Id. Smith added the qualification that an actor "might be put on notice by the woman's configurations if the pregnancy is advanced, or by statistical probabilities if his conduct is directed toward a crowd." Id.

137. Victorian Rys. Commrs. v. Coultas, 13 App. Cas. 222 (P.C. 1888).

138. Smith, supra note 124, at 285.

139. Id. at $239 \mathrm{n} .152$.

140. For example, Smith stated that mothers were foreseeable victims if the child endangered were "in his own yard or house" or were younger than seven years old. In these cases a parent could be expected to be close by "hovering over her "chick." II.

141. Smith \& Solomon, supra note 124 , at 117.

142. Id. at 112 . 
aid of "competent directors and producers,"143 used the legal system as "a special stage for the enactment of a drama calculated to overthrow jury conservatism." 144 In the final summary to his primary article, Smith made explicit his awareness of gender and his lack of receptivity to the claims of plaintiffs. After asserting that his study of 301 cases "gives one a 'feeling tone' not to be had from studying a single case," 145 Smith presented a case count to support his view that courts ought to be deeply skeptical of claims of fright-based injury. He claimed that in 216 of the 301 cases the plaintiff possessed a "preexisting vulnerability" 146 that should have barred recovery. Smith thought that the courts had been altogether too lenient to plaintiffs. His oft-quoted final assessment was that " $[t]$ he net balance of justice in the years 1880-1944 would have been greater had redress been denied in all cases of alleged injury from psychic stimuli." 147

Smith was the first commentator to quantify the extent to which psychic injury claims were dominated by female plaintiffs. He found that the ratio of female plaintiffs to male among his 301 cases was a striking 5:1.148 His analysis of this gender disparity combined an odd mixture of conservative imagery and sociological speculation. Smith asked, "Is the fairer sex also the frailer in its resistance to psychic stimuli?" 149 He suggested that pregnant women might be more sensitive to stimuli and offered the "comparative conditioning of the two sexes to environmental stress and to psychological factors"150 as an explanation of why fright causes sickness more often in women than in men. Smith even ventured to explain why women sue more often in impact cases: "We might theorize that more women than men suffer 'injury from without,' either because they frighten more easily or in fleeing from apprehended peril, are handicapped by lack of athletic prowess or masculine agility and so fall victim to comparative clumsiness." 151

143. Id. at 118 .

144. Id. at 115 .

145. Smith, supra note 124 , at 278.

146. Id. at 282 .

147. Id. at 303. Earlier in the article, Smith had added 30 years to his assertion about the "net balance of justice," covering the period from 1850 to 1944. Id. at 285 .

148. Id. at 280 . We were unable to verify the accuracy of Smith's ratio. Smith's two appendices of cases contain 565 entries. There are, however, some cases listed more than one time and some cases in which the parties plaintiff included both a man and a woman. Our recount of Smith's cases reveals only 281 distinct cases, with 57 male plaintiffs and 224 female plaintiffs. By this count, there is only a 4:1 female-male ratio. This count also reveals 54 miscarriage cases, approximately $20 \%$ of the total cases.

149. Id.

150. Id.

151. Id. 
Smith's final speculation is somewhat more plausible. He suggested that the gender disparity among plaintiffs in psychic injury cases might reflect prevailing sex-role stereotypes more than actual events:

[I] $t$ may be that in cases of alleged injury through psychic stimuli, attorneys encourage suit if they have a lady litigant and discourage it if the claimant be a male.... It well may be that the male ego is too compromised by claiming injury through fright, this deterrent to suit being bolstered by social taboos. After all, one has to face a jury, and he does not like to become an ass before his fellow man. A woman's "femininity" is not hurt by such a claim. A certain amount of fragility is expected and esteemed. ${ }^{152}$

To bolster his argument that fright rarely caused physical injury to average or normal persons, Smith drew an analogy between nervous shock in civilian life and combat neuroses. Drawing on what was understood in the mid-years of World War II about combat stress, Smith wrote that "there is reason to think that many soldiers who suffer major psychiatric crack-up, such as neurosis or psychosis[,] came up to these gruelling experiences possessed of subnormal resistance." 153 Skeptical of both the claims of women in fright cases and of men who claimed combat neurosis, Smith saw the situations as analogous because he believed that, in both settings, the victim stood to gain by pleading weakness - a situation otherwise uncommon.

Smith's turn to the combat analogy was not farfetched. In premodern societies, people often assumed a rough congruence between the physical risk to which men were put in battle and the physical pain and risk that women experienced in childbirth. ${ }^{154}$ Moreover, the concept of combat stress was in Smith's day intensely discussed by military physicians who were under considerable pressure to find ways to distinguish authentic cases from malingering, that is, simple fright. ${ }^{155}$ Smith himself was hostile to all claims based on fright; they

152. Id.

153. Id. at 286.

154. Huston, The Matrix of War: Mothers and Heroes, in THE FEMAlE BODY IN WESTERN Culture 119, 127 (S. Suleiman ed. 1986).

155. The official history of The Army Air Forces in World War II, for example, compiled by the Air Force Historical Division in 1958, dismissed consultations from psychologists and psychiatrists as often adding "to the confusion," 7 UNITED STATES AIR FORCE Historical DiviSION, THE ARMY AIR FORCES IN WORLD WAR II 416 (1958), and comfortably asserted: "Twelve years after the end of the war one fails to see the grave psychic consequences of pushing men to - and beyond - what many then considered the breaking point." Id. at 404 .

During World War II, psychiatrists in both England and the United States tended to assume that "combat neurosis" or "war neurosis" was not a distinctive condition. As W. Ronald D. Fairbairn asserted in the British Medical Journal in 1943, "so far as symptomatology is concerned, the war neuroses possess no distinctive features differentiating them sharply from the various psychoneurotic and psychotic states which prevail in time of peace." Fairbairn, The War Neuroses: Their Nature and Significance, BRIT. MED. J., Feb. 13, 1943, at 183. Fairbairn ended 
were due, he concluded, to the preexisting personal weaknesses of the victims and not to the aggressive acts of the "prime movers,"156 whether the latter was a private citizen driving a car negligently or the state in the act of conducting a war. ${ }^{157}$

Overall, there is a vicious circularity to Smith's central argument. The abnormality of fright-based physical harm is proven by the idiosyncratic nature of the person experiencing the harm. But Smith's characterization of both the harm and the plaintiff is premised on a male- oriented - at times misogynist - standard of the "normal" person. ${ }^{158}$ Smith's application of Freud to legal doctrine prompted him to notice gender but in the process to reinforce gender inequality. His argument faults women for not conforming to his stereotype of combat-ready men.

\section{From Bystander to Mother: The Amaya and Dillon Cases, 1962-1968}

\section{Amaya v. Home Ice, Fuel \& Supply Co.}

The breakthrough case that first permitted recovery for mothers who witnessed their children's injury was a California appellate decision written by Justice Matthew O. Tobriner in 1962. At the time Amaya v. Home Ice, Fuel \& Supply Co. ${ }^{159}$ was decided, the courts seemed to be hardening their stance against recovery in "bystander"

by denying the existence of combat neurosis completely. What was being seen, he argued, was regression to an infantile state and a symptom of separation anxiety. He concluded, "I remain convinced that ... the problem presented by the war neuroses is not one of psychotherapy but one of morale." Id. at 186. In arguing for predisposition, Smith reflected the opinions of military psychiatrists of his generation. See Gowan, Psychiatric Aspects of Military Disabilities, 41 U.S. Naval Med. Bull. 129 (1943); Schwab, Feinsinger, \& Brazier, Psychoneuroses Precipitated by Combat, 42 U.S. Naval Med. Bull. 535 (1944).

156. In this and other articles, Smith often referred to the defendant as the "prime mover." See, e.g., Smith, supra note 124, at 229 n.128 (arguing against liability for negligent infliction of mental distress without accompanying physical injury because "the prime mover in society would be unduly penalized and prevalent neurotic patterns in the populace encouraged"); $i d$. at 269. As late as 1963, Smith expressed his concern that a "neurotic personality" would be given "tremendous damages" as a result of "minimal traumatic experience suffered at the hands of a wholesome prime mover, seeking to advance social interests by exercising Yankee ingenuity and industry." Smith, Problems of Proof in Psychic Injury Cases, 14 SYRACuSE. L. Rev. 586, 624 (1963).

157. What Smith did not observe, however, is that soldiers, like many women, find themselves in structural situations in which they are denied autonomy and choice. See C. SMITHROSENBERG, supra note 31, at 331 n.5.

158. In the one instance in which Smith theorizes about the standard for determining "what sort of neighbor" defendants must take care to protect, he uses exclusively male examples: "Shall it be the sturdy phlegmatic chap who has been building up his biceps at the Y.M.C.A., the fragile fellow whose resistance is subnormal, or the average man in normal health, toughened and seasoned by everyday stimuli of the knock-about world?" Smith, supra note 124, at 254-55.

159. 23 Cal. Rptr. 131 (Cal. App. 1962), revd., 59 Cal. 2d 295, 379 P.2d 513, 29 Cal. Rptr. 331 (1963). 
cases, except in the rare "danger zone" situation in which the plaintiff was also physically imperiled. ${ }^{160}$ The most prominent advocate for extending recovery to mothers and other witnesses - William Prosser - had reluctantly admitted in his role as Reporter to the Second Restatement of Torts that the most recent case law was decidedly against plaintiffs. The drafters of the Second Restatement went on record in 1960 as embracing a definite rule against liability in bystander cases. ${ }^{161}$

The courts' reluctance to award parents damages for shock at witnessing the death or injury of their child, however, was in tension with an increasing willingness on the part of the insurance industry and the courts in other contexts to place a monetary value on children's lives and to commodify the parent-child relationship. ${ }^{162}$ The seeming paradox of "pricing the priceless child" 163 had already been transcended in the more typical suits for wrongful death of a child where the parent did not actually witness the injury. ${ }^{164}$ Until Amaya, however, the courts had resisted taking the further step of permitting recovery for fright-based harm suffered by parents present at the scene of the accident.

Amaya had all the ingredients of the paradigm fright-based injury case. Lillian Amaya watched from a distance of eighty feet as her seventeen-month-old son was crushed beneath the wheels of a negligently driven ice truck in the driveway of their home. ${ }^{165}$ Lillian

160. See W. Prosser, TORTS, supra note 121, at 352-53.

161. In a note to the Institute, Prosser explained the decision to add a new subsection denying recovery in "bystander" cases. This was more restrictive than the First Restatement, which had included a "caveat" withholding opinion on the rights of parents or spouses who witnessed the peril or harm of their children or spouse. Prosser wrote:

The Caveat is stricken - and Subsection (2) is substituted, because of the overwhelming weight of the case law. The Advisers were unanimous in wishing to retain the Caveat, for its possible effect upon the courts - although it must be conceded that it has thus far had no effect. The Reporter is in sympathy with this position, and feels that there should be liability to a mother who suffers a heart attack when she sees her child killed before her eyes. $\mathrm{He}$ is compelled, however, to recognize that the decisions are otherwise. The Council are agreed that the Caveat should go out, and the definite rule of non-liability should be stated. RESTATEMENT (SECOND) OF TORTS § 313, at 9 (Tent. Draft No. 5 1960).

162. By 1895 , there was a large market for insuring children's lives. Supporters of the insurance industry defended the business as a symbolic means of demonstrating parental love. $V$. Zelizer, Pricing the Priceless Child 115, 127 (1985).

163. See id. Zelizer developed the theory that the increased commercialization of children paradoxically was supported by an ideology that viewed children as the sentimental, priceless assets of their parents, particularly their mothers. Zelizer considered these developments as infusing money with a symbolic meaning and simultaneously permitting an economic valuation of non-economic injuries. Id. at 159-60, 211-12.

164. See id., at 147-60; see also Siciliano v. Capital City Shows, Inc., 124 N.H. 719, 728, 475 A.2d 19, 23 (1984) (35 jurisdictions allow for loss of companionship to parents in wrongful death actions); Green v. Bittner, 85 N.J. 1, 424 A.2d 210 (1980).

165. See Recent Developments, 15 STAN. L. REv. 740, 744 n.13 (1963) (citing letter from plaintiff's counsel, James Oppen (Oct. 16, 1962)). 
Amaya was seven months pregnant at the time of the accident and claimed that the trauma of the event produced physical shock and other bodily injuries. ${ }^{166}$ She refused the opportunity to amend her complaint to allege that she also feared for her own physical safety and insisted that her only fear was for the safety of her child. ${ }^{167}$

Justice Matthew Tobriner had a well-established reputation as a jurist of great distinction and intellectual force. Educated at Stanford and Harvard, he had spent his early career as a lawyer for labor unions and agricultural cooperatives in the 1930s and 1940s. After several decades in private practice, Tobriner was appointed to the California Court of Appeals in 1959.168 Amaya was one of the last opinions he wrote there; later in 1962 he was appointed to the California Supreme Court. ${ }^{169}$

Justice Tobriner's ruling for the intermediate appellate court in favor of Amaya was self-consciously reformist. Although he attempted to discount the significance of some of the adverse precedents, Tobriner's basic strategy was to declare that the prevailing view was fundamentally unjust and simply "not consonant with the reactions, or the mores, of the society of today."170 In this first round of the debate in the California courts on bystander recovery, Tobriner did not elaborate on the contemporary conditions that compelled the conclusion that mothers who witnessed the negligent injuring of their children deserved compensation. He made only a passing reference to the "teachings of psychiatry" to undercut the familiar argument that emotional disturbance is too hard to measure or too easy to fake. ${ }^{171}$ For the most part, Tobriner's public policy argument for recovery in Amaya was unstated. He proceeded from the assumption that it was "obvious" 172 that a denial of recovery to mothers is unfair, and sought to expose contrary legal precedent as "anachronistic"173 without stat-

166. Amaya, 23 Cal. Rptr. at 132. A student commentator has asserted that the only injuries Lillian Amaya sustained were recurring nightmares. Recent Developments, supra note 165, at $740 \mathrm{n} .1$ (citing letter from plaintiff's counsel, James Oppen (Oct. 16, 1962)).

167. 23 Cal. Rptr. at 133. We do not know why Lillian Amaya made this potentially damaging concession. Perhaps because she was located so far from the accident scene she could not credibly claim fear for her own personal safety. It is also possible that her refusal to amend reflected her own experience of the trauma and that she refused to misrepresent her experience or accede to a legal system that denied recovery for this relationally oriented harm.

168. See generally Grodin, Justice Tobriner: Portrait of the Judge as an Artist, 29 HAsTings L.J. 7 (1977).

169. Tobriner, Can Young Lawyers Reform Society Through the Courts?, 47 CAL. ST. B.J. 294 (1972)

170. Amaya, 23 Cal. Rptr. at 140 .

171. $23 \mathrm{Cal}$. Rptr. at 140 .

172. 23 Cal. Rptr. at 133 (citing W. PROSSER, supra note 97, at 181).

173. 23 Cal. Rptr. at 141 . 
ing exactly what had changed.

Tobriner's ruling for the plaintiff in Amaya was reversed by the California Supreme Court in a 4-3 decision. ${ }^{174}$ In fact, the result was even closer than the split indicated. By the time of the supreme court ruling, Justice Tobriner had himself been elevated to the supreme court. Unfortunately for the plaintiff, however, Tobriner was required to recuse himself from the Amaya litigation in the supreme court because he had decided the case in the lower court. The judge sitting in for Tobriner supplied the critical vote against the plaintiff to produce the very shakiest of precedents against recovery. ${ }^{175}$

The supreme court's majority opinion in Amaya relied heavily on the scholarship of both Leon Green and Hubert Winston Smith to justify its refusal to recognize a cause of action. The court used Green's work ${ }^{176}$ to support its claim that it was the function of the court, not the jury, to declare a rule of nonliability based upon its weighing of the various administrative, socio-economic, and moral factors present in this type of case. ${ }^{177}$ The court thus turned Green's realist identification of the operational factors at work in cases already decided into a conservative argument in favor of the status quo. The majority avoided defending the logic of the restrictive rule by borrowing Green's realist balancing of societal interests.

From Smith's article, ${ }^{178}$ the majority drew support for its skeptical appraisal of the medical reality underlying the claims for fright-based injuries. The court endorsed Smith's view that justice would be better served by denying recovery altogether in this type of case. ${ }^{179}$ The court accepted as fact Smith's assertion that most of the plaintiffs claiming injury in fright-based physical harm cases possessed subnormal resistance to fright and did not deserve to recover. ${ }^{180}$

By using the term "spectator injury"181 to describe Lillian

174. Amaya v. Home Ice, Fuel \& Supply Co., 59 Cal. 2d 295, 379 P.2d 513, 29 Cal. Rptr. 33 (1963) (en banc).

175. Justice White, pro tem, concurred while sitting in for Justice Tobriner in Amaya. 59 Cal. 2d at 332, 379 P.2d at 536, 29 Cal. Rptr. at 56.

176. Green, The Duty Problem in Negligence Cases, 28 Colum. L. REv. 1014 (1928).

177. $59 \mathrm{Cal} .2 \mathrm{~d}$ at 308-15, $379 \mathrm{P} .2 \mathrm{~d}$ at 521-25, $29 \mathrm{Cal}$. Rptr. at 41-45.

178. Smith, supra note 124. For a discussion of this article, see supra notes 124-58 and accompanying text.

179. 59 Cal. $2 d$ at 311,379 P.2d at 523, 29 Cal. Rptr. at 43; see also supra note 147 and accompanying text.

180. "Much timeliness remains in Dr. Smith's warning . ... that 'eagerness to be progressive may cause extravagant credulity and injury to scientific standards of proof.' Extravagant credulity, of course, means ultimate injustice." 59 Cal. App. 2d at 312, 379 P.2d at 523, 29 Cal. Rptr. at 43.

181. Amaya, 59 Cal. $2 \mathrm{~d}$ at 514, 379 P.2d at 525, 29 Cal. Rptr. at 45. 
Amaya's harm, the majority cast her injuries in an unsympathetic light. Like the term "bystander," the "spectator" image likens a mother's injury to the emotional response of any witness and places no special weight on her relationship to her child. This aspect of the majority opinion infuriated dissenting Justice Raymond E. Peters. Peters' opinion emphasized that "[ $t$ ] he plaintiff here is not just anyone. She is a mother of a 17-month-old infant child."182 The split in the court in Amaya was between the majority's view of the plaintiff as a bystander and the dissent's focus on the plaintiff as a mother.

\section{Dillon v. Legg}

Only five years after deciding Amaya, the California Supreme Court overruled it in Dillon v. Legg. 183 Justice Tobriner wrote for the new majority in 1968. He stressed that the plaintiff was a mother, not an ordinary bystander, who witnessed the negligent killing of her child. For Tobriner, this type of case was "the most egregious case of them all: the mother's emotional trauma at the witnessed death of her child." 184

The facts of Dillon closely resembled Amaya. On September 27, 1964, Margery Dillon was sitting on the porch of her home in Sacramento watching her four-year-old daughter Erin cross the street. At the time of the accident, Erin's older sister Cheryl was also on the curb nearby. Both Margery Dillon and Cheryl saw Erin struck and killed by a car negligently driven by David Legg. Margery Dillon's complaint alleged that she suffered both physical and emotional injuries from witnessing the death of her child. ${ }^{185}$

The only arguably relevant factual distinction between Amaya and Dillon was that, in the latter case, Cheryl, but not her mother, was in the "danger zone" - Cheryl was located sufficiently near the accident to have feared for her own safety, as well as the safety of her sister. Under prevailing precedent that allowed recovery only to witnesses who were within the danger zone, Cheryl stood a chance of recovering for her fright-based trauma while her mother did not. ${ }^{186}$

182. 59 Cal. 2d at 316, 379 P.2d at 526, 29 Cal. Rptr. at 46 (Peters, J. dissenting) (emphasis in original).

183. 68 Cal. 2d 728, 441 P.2d 912, 69 Cal. Rptr. 72 (1968) (en banc).

184. $68 \mathrm{Cal} .2 \mathrm{~d}$ at $747,441 \mathrm{P} .2 \mathrm{~d}$ at $925,69 \mathrm{Cal}$. Rptr. at 85 .

185. Dillon v. Legg, Complaint at 4.

186. Cheryl Dillon's claim survived pretrial dismissal because there was a possibility that she was in the zone of danger at the time of the accident. $68 \mathrm{Cal} .2 \mathrm{~d}$ at 732, $441 \mathrm{P.2d}$ at $915,69 \mathrm{Cal}$. Rptr. at 75 . Because Margery Dillon was clearly outside the danger zone, her claim was dismissed on the pleadings based on the Amaya precedent. $68 \mathrm{Cal}$. 2d at 732, $441 \mathrm{P} .2 \mathrm{~d}$ at 915,69 Cal. Rptr. at 75 . 
Tobriner would not allow the ruling in Dillon to depend on this narrow factual distinction. Instead he flatly rejected the danger zone approach as a "hopeless artificiality" 187 that would produce the anomalous result of granting "relief to the sister ... and yet deny it to the mother merely because of a happenstance that the sister was some few yards closer to the accident."188 The new rule announced in Dillon was that liability would depend on the more flexible test of whether the accident and the harm were reasonably foreseeable. ${ }^{189}$ Tobriner expressly noted that the closeness of the relationship between the plaintiff and the victim should be a key determinant of foreseeability. ${ }^{190}$ The old physical danger zone was transformed by Tobriner into a larger zone of emotional danger.

In Dillon, Tobriner made it clear that he was an unapologetic judicial activist, shaping the law to accommodate social change. But it was clear also that his was a cautious activism, that his vision of appropriate change emerged from a long historical perspective and from a liberal's skepticism of letting traditional categories get in the way of equitable solutions. It was "indefensible orthodoxy" that Tobriner opposed. ${ }^{191}$

187. 68 Cal. $2 \mathrm{~d}$ at $733,441 \mathrm{P} .2 \mathrm{~d}$ at $915,69 \mathrm{Cal}$. Rptr. at 75 .

188. $68 \mathrm{Cal}$. 2d at $733,441 \mathrm{P} .2 \mathrm{~d}$ at $915,69 \mathrm{Cal}$. Rptr. at 75 .

189. 68 Cal. $2 \mathrm{~d}$ at $741,441 \mathrm{P} .2 \mathrm{~d}$ at $920,69 \mathrm{Cal}$. Rptr. at 81 .

190. $68 \mathrm{Cal} .2 \mathrm{~d}$ at 741, $441 \mathrm{P} .2 \mathrm{~d}$ at $920,69 \mathrm{Cal}$. Rptr. at 80 . The Court struggled, however, with the problem of precisely which relationships would qualify as close enough for recovery. At one point, the issue was brought close to home by Justices Peters and Traynor, who wondered aloud whether "grandpas" could recover under the new standard. Record at 3.

191. $68 \mathrm{Cal} .2 \mathrm{~d}$ at $748,441 \mathrm{P} .2 \mathrm{~d}$ at $925,69 \mathrm{Cal}$. Rptr. at 85 . Later in his career, Tobriner would energetically defend judicial activism. He wrote:

[L]aw, as an instrument of social control, must, by necessity, respond to the emerging pressures for change within our society, and, if the legal system is to remain viable in the face of today's rapidly shifting mores, we acutely need the advocates of change.... In recent years the judicial system has proven itself capable of grasping the significant movements that have changed the complexion of our culture, and of shaping legal relationships to accommodate new social patterns and to preserve cherished freedoms.

Tobriner, supra note 169 , at $296-98$.

Tobriner was an advocate for ending discrimination against gays and lesbians, racial minorities, and women. See Gay Law Students Assn. v. Pacific Tel. \& Tel. Co., 24 Cal. 3d 458, 595 P.2d 592 (1979) (public utilities could not engage in employment discrimination against homosexuals). Tobriner's career would culminate in his two most famous opinions, his opinion for the majority in Marvin v. Marvin, 18 Cal. 3d 660, 557 P.2d 106, 134 Cal. Rptr. 815 (1976), and his dissent in Bakke v. Regents of the Univ. of Cal., 18 Cal. 3d 34, 553 P.2d 1152, 132 Cal. Rptr. 680 (1976), modified, 438 U.S. 265 (1978). In Marvin, popularly known as the "palimony" case, the new social pattern that Tobriner was willing to accommodate was nonmarital cohabitation. "[W]e believe," he wrote, "that the prevalence of nonmarital relationships in modern society and the social acceptance of them" is a matter which courts should acknowledge; the "nonmarital relationship of today" was not the equivalent of the "meretricious relationship" that the law had traditionally understood to be prostitution. 18 Cal. 3d at 683, 557 P.2d at 122, $134 \mathrm{Cal}$. Rptr. at 838. In Bakke, the social change Tobriner wished to support was the integration of black students into medical schools. His dissent remains an eloquent defense of affirmative action as entirely consistent with the goals of the fourteenth amendment. 
Dillon set a new legal course based on what Tobriner described as the "natural justice" of the mother's claim. 192 "Dillon is unique," Tobriner asserted in a reflective essay two years after the decision, "in its emphasis upon the rights of the victim as opposed to a historical concern with the violation of a duty of due care."193 As he worked out his justification for extending the rights of the victim and the scope of the defendant's responsibilities, Tobriner envisioned the victim not simply as Margery Dillon the person, but as Margery Dillon the mother, whose presence on the scene of the accident was inextricably linked to her role as parent. ${ }^{194}$ The view of the world embedded in Tobriner's opinion is one in which fathers go to work and mothers care for their children, a world in which children are central to their mothers' emotional lives. ${ }^{195}$ Tobriner was only narrowly reversed on appeal in Amaya; his decision there is not very different from the one that "stuck" in Dillon. As a liberal judge writing in the 1960s, he was already deeply committed to expanding the rights of those who experienced loss, and he was willing to open up the categories of legal harm and duty.

Tobriner was conscious of and made use of the gender of the plaintiff in his opinion in Dillon. Much of Tobriner's opinion is written in gender-specific language (mother, rather than parent) although he ultimately articulated the criteria for recovery in future cases in genderneutral terms. ${ }^{196}$ Tobriner deployed the gender of the plaintiff both to guarantee the genuineness of the injury suffered and to argue for the foreseeability of the injury. His use of gender and maternity, however, was not woven explicitly into his legal rationale for a new doctrine. For example, Tobriner did not explain why it took until 1968 to recognize this obviously just claim for maternal injury. He pointed to no specific changed social circumstances, beyond an oblique reference to "modern medical knowledge" 197 as support for treating fright on a par with physical impact. He drew no connection between the "indefen-

192. 68 Cal. 2d at 731,441 P.2d at 914,69 Cal. Rptr. at 74.

193. Tobriner, The Changing Concepts of Duty in the Law of Torts, 9 CAL. TRIAL Law. J. 17,19 (1970) (emphasis in original). banc).

194. Record at 25, Dillon v. Legg, 68 Cal. 2d 728, 441 P.2d 912, 69 Cal. Rptr. 92 (1968) (en

195. This world view permeated the oral argument. For example, Archie Hefner, Dillon's attorney, repeatedly stressed that mothers would naturally be at their children's side: "[I]f you and I were there, and we saw children, we would certainly anticipate on a given day of the week that their mothers certainly would not be very far away." Record at 8 .

196. The cause of action was not limited explicitly to mothers; the courts were asked only to consider the closeness of the relationship between the plaintiff and the victim in deciding the foreseeability of the plaintiff's response. See supra note 25.

197. Dillon v. Legg, 69 Cal. Rptr. 72, 80 n.5, 441 P.2d 912, 920 n.5 (1968). 
sible orthodoxy"198 underlying the more restrictive doctrines and societal bias against women. Nor did the fact that Margery Dillon was a divorced parent of limited financial resources ${ }^{199}$ who may have had a particularly compelling need for legal recognition of her interests find its way into his opinion.

\section{Rediscovering Dillon: A Feminist Perspective, 1990}

Neither Margery Dillon nor her lawyers, so far as we can tell, understood their victory in terms of women's rights. It is also unlikely that the judges who dissented in $A m a y a^{200}$ or joined the majority in Dillon understood themselves to be responding directly to the gendered nature of the issues in these cases. Subsequent legal commentators have also ignored the role that gender played in Dillon. ${ }^{201}$

The recognition of the cause of action in Dillon, however, has an ideological dimension that, like the fright precedents before it, is tied to gender. Dillon should also be mined for what it can tell us about cultural attitudes in the 1960 s, especially about the relationships between women and their children and how those relationships bear on the physical well-being of women. Timing is crucial. "Mother love" surely was not a creation of America in the 1960s. Why then did it take so long for the courts to produce Dillon?

198. $68 \mathrm{Cal} .2 \mathrm{~d}$ at $748,441 \mathrm{P} .2 \mathrm{~d}$ at $925,69 \mathrm{Cal}$. Rptr. at 85.

199. Dillon's attorney did, however, alert the California Supreme Court to these personal facts about his client. At oral argument he first described Margery Dillon as divorced, although he quickly added that that fact was not material to the case. Record at 1 . At another point, he described Margery Dillon's residence as a "small house," giving the impression that she was not well off financially. Record at 8 . It appears that Margery Dillon supported her children without help from her ex-husband. In her wrongful death complaint, Dillon alleged that her ex-husband had not contributed materially to Erin's support and maintenance before her death. Complaint at IIII.

200. Amaya v. Home Ice, Fuel \& Supply Co., 59 Cal. 2d 295, 379 P.2d 513, 29 Cal. Rptr. 33 (1963) (en banc).

201. Several commentators have been critical of the "liberal" Dillon holding because of their concern with limiting costs for defendants and lessening the strain on the courts. See, e.g., Diamond, Dillon v. Legg Revisited: Toward a Unified Theory of Compensating Bystanders and Relatives for Intangible Injuries, 35 HASTINGS L.J. 477 (1984); Henderson, Expanding the Negligence Concept: Retreat from the Rule of Law, 51 IND. L.J. 467 (1976); Miller, The Scope of Liability for Negligent Infliction of Emotional Distress: Making "The Punishment Fit the Crime," 1 U. HAw. L. REV. 1 (1979); Pearson, Liability to Bystanders for Negligently Inflicted Emotional Harm - A Comment on the Nature of Arbitrary Rules, 34 U. FLA. L. REV. 477 (1982).

Guido Calabresi is one of the few commentators who goes beyond cost-benefit assessments to acknowledge tort law's role in "shaping tastes." Calabresi claims that the law is more likely to compensate for an emotional cost when the harm is intuitively "shocking, offensive, and even abominable." G. CALABRESI, Ideals, BEliefs, ATtitudes AND the LAW 83-84 (1985). He makes sense of Dillon by reading the case as an indicator that society does not want people to become callous about seeing their children or spouses killed, whereas society might be better off if nonrelated individuals (i.e., true bystanders) were encouraged to shrug off the emotional impact of seeing another person injured or killed. $I d$. 
It is a truism that court decisions swim like fish in a sea of ideology. "[W]e can never," Benjamin Cardozo wrote long ago, "see . . . with any eyes except our own."202 The years between 1960, when an ice truck injured James Amaya, and 1968, when Tobriner handed down the California Supreme Court's decision in Dillon, were transitional years in American social history. They marked the end stages of an era that we remember as "the cold war," a period usually dated from 1945 to 1965 or so, in which an overarching demand for security in foreign affairs filtered into a "domestic revival" that offered marriage and motherhood as the only appropriate roles for women. ${ }^{203}$ "The cold war consensus and the pervasive atmosphere of anticommunism made personal experimentation, as well as political resistance, risky endeavors with dim prospects for significant positive results," writes historian Elaine Tyler May. ${ }^{204}$ In this atmosphere, "[p]rocreation . . . took on almost mythic proportions. . . . [P] arenthood [was] the key not only to responsible citizenship and a secure future but to a personally fulfilling life. . . . Along with the baby boom came an intense and widespread endorsement of pronatalism the belief in the positive value of having several children."20s The family, particularly the mother, became a symbol of stability and security.

This ideology was sustained despite the fact that mothers increasingly worked outside the home; in 1960, forty percent of women over sixteen held a job, and one-third of working women were mothers of children under eighteen. ${ }^{206}$ In the face of changing economic reality, many elements in American society sought to dissuade mothers from thinking of themselves as independent from their children and thus to preserve the cult of domesticity. In newspaper accounts, even women of substantial professional accomplishment "were carefully described as mothers first."207 In a social context in which women's identities were understood to be motherly and domestic, even women's political action had to find a domestic language in which to express itself. As Amy Swerdlow's study of Women Strike for Peace has shown, when thousands of women wanted to protest atomic bomb testing in 1961, they found that the most effective strategy - indeed, the only effective

202. B. Cardozo, The Nature of the Judicial Process 13 (1921).

203. This social and ideological development has recently received insightful historical analysis in E. MAY, Homeward Bound: AMERICAN FAMILIES IN THE COLD WAR ERA (1988).

204. Id. at 207.

205. Id. at 135-37.

206. W. Chafe, The American Woman: Her Changing Social, Economic, and Polttical Roles, 1920-1970, at 218 (1972).

207. E. KALEdiN, MOTHERS AND MORE: AMERICAN WOMEN IN THE 1950S 65 (1984). 
strategy - available to them was to organize as mothers who feared for the health of their children and who worried particularly about strontium-90 in milk. Any other stance was vulnerable to being attacked as unwomanly, un-American, and pro-Communist. ${ }^{208}$

The valuing of children and the privileging of the maternal relationship that pervaded the domestic ideology of the cold war period might well have reinforced Lillian Amaya's and Margery Dillon's sense that they personally had been wronged by harms to their children and strengthened their decisions to seek compensation for their own suffering. Clearly the lawyers for Amaya and Dillon emphasized the special "maternal" nature of the injuries their clients suffered. Lillian Amaya's complaint, for example, underscored her role as mother and mother-to-be: she alleged that at the time of the accident, she was "in a state of pregnancy that had advanced to approximately seven months; that the natural maternal bonds of affection existed between plaintiff and her infant son."209 At the oral argument before the California Supreme Court, Margery Dillon's lawyer spoke of the "traditional classic concept of motherhood ... which we all admire and look up to."210 It was thus in their roles as mothers that Lillian Amaya and Margery Dillon came before the courts.

The Dillon cause of action signifies that the law regards a mother's anguish at witnessing the death or injury of her child as a harm that qualifies for legal protection. This recognition of the claims of mothers was congruent with the deeply domestic political ideology of cold war society.

The Dillon opinion was also congruent with a traditional view of women as the normal caretakers of their young children. The court refuted the defendant's contention that a mother/witness was an unforeseeable plaintiff in child pedestrian cases by stating what it thought to be the obvious: mothers were often likely to be found in the vicinity of their young children. ${ }^{211}$ The opinion also revealed a sentimental view of maternity. In criticizing the requirement that recovery must be predicated on the plaintiff's fear for her own personal safety, Tobriner commented on the example in the Hambrook ${ }^{212}$ case of the selfish

208. Women Strike for Peace was a loosely organized coalition of women based in ParentTeacher Associations, Leagues of Women Voters, church and temple groups, and established peace organizations. See Swerdlow, Ladies Day at the Capitol: Women Strike for Peace versus HUAC, 8 FEMINIST STUd. 493 (1982).

209. Complaint at ๆ II, Amaya v. Home Ice, Fuel \& Supply Co., 59 Cal. 2d 295, 379 P.2d 513, 29 Cal. Rptr. 33 (1963) (en banc).

210. Record at 9, Dillon v. Legg, 68 Cal. 2d 728, 441 P.2d 912, 69 Cal. Rptr. 72 (1968).

211. $68 \mathrm{Cal}$. $2 \mathrm{~d}$ at $741,441 \mathrm{P} .2 \mathrm{~d}$ at $921,69 \mathrm{Cal}$. Rptr. at 81.

212. Hambrook v. Stokes Bros., 1 K.B. 141 (1925). 
mother who fears only for her own safety and the selfless mother who cares only for the safety of her child.213 Tobriner thought that it would be "incongruous and somewhat revolting" to let the selfish mother recover and deny recovery to the selfless mother. ${ }^{214}$ The normative judgment that mothers should place the well-being of their children ahead of their own comes out clearly. The image of the "good mother" emerges; it is the good mother who is afforded legal relief. 215

It is also clear that the Dillon judges were writing in the intensely political year 1968, toward the end of a decade in which both the civil rights and anti-war movements had been conducting a national teachin, as it were, on the topic "the personal is political." The Presidential Commission on the Status of Women, chaired by Eleanor Roosevelt, had been established in 1961. Betty Friedan's manifesto The Feminine Mystique had been published in 1963, one year after the Amaya decision was handed down. When Dillon was decided, a two-year-old National Organization of Women had articulated a call for an equal rights amendment, for access to safe, legal abortions, and for the enforcement of antidiscrimination legislation. In 1968, feminists picketed the Miss America pageant. ${ }^{216}$ If the rhetoric of the Dillon opinion looks back to the privileging of motherhood and the superficial separation of spheres that characterized the 1950 s, the result in Dillon is also congruent with the feminist movement as it would grow in the five years following 1968, culminating in the Roe v. Wade 217 decision of 1973. Despite the sentimentality for motherhood it encompassed, Dillon pushed against the marginalization of recurring injuries in the lives of women and gave women a claim of legal right. A decision that had the concrete effect of putting money into the hands of women through the redistributive mechanism of tort liability may be understood to serve women's interests.

From this perspective, Dillon deserves to be placed with other rights-affirming precedents of the last two decades that have been par-

213. Record at 25, Dillon; this example from Hambrook is set forth supra at note 102 and accompanying text.

214. 68 Cal. 2d at 738 n.4, 441 P.2d at 918-19 n.4, 69 Cal. Rptr. at 79 n.4.

215. Nancy Pottishman Weiss has traced shifting child care advice from the Progressive reformers' concern for sensible mothering practice to the permissive, child-centered advice of Benjamin Spock. Weiss, Mother, the Invention of Necessity: Dr. Benjamin Spock's Baby and Child Care, 29 AM. Q. 519 (1977). For a discussion of how the law favors the "good mother" in both reality and fiction, see Sanger, Seasoned to the Use (Book Review), 87 Mich. L. REv. 1338 (1989).

216. See De Hart-Mathews, The New Feminism and the Dynamics of Social Change, in Women's America: Refocusing the Past 446 (L. Kerber \& J. De Hart-Mathews 2d ed. 1987).

217. 410 U.S. 113 (1973). 
ticularly important to women. The most familiar of these legal developments are changes in public law, particularly expansion of the constitutional notion of equality that has been employed since 1971 to restrict explicit sex-based discrimination. ${ }^{218}$ Tort law has also been part of this movement. For example, the first recognition of a cause of action in tort for "wrongful birth" came in 1967,219 a year before Dillon was decided. This claim allows women to hold their obstetricians accountable for unwanted pregnancies that were caused in part by the physician's negligent treatment or diagnosis. The wrongful birth cause of action complements the Dillon claim in that it gives legal recognition to the interest women have in their relationship to their unborn children. The wrongful birth cause of action pressures health professionals to make sure that a pregnant woman (or a woman contemplating pregnancy) is advised of any condition that might affect her own well-being or that of her unborn child. By enlarging the physician's duty, this cause of action tends to expand the notion of women's health to include reproductive health and health of offspring.

This account of Dillon also tends to validate women's expanded role outside the domestic sphere. The legal/market valuation placed on women's fright-based injury has the effect of mainstreaming the injury. Dillon's willingness to protect pregnancy and maternal interests outside the narrow confines of the home contrasts with the Victorian view that these activities had their proper site inside the home.

As the fright-based injury is deprivatized, the law regards it as less unusual, less remote, and more deserving of protection. The "reasonable man" of tort law is redefined to encompass the mother. When a mother's fear for her child is acknowledged as a cause of her own physical harm, we can glimpse the beginnings of a feminization of tort law. Relational interests become a constituent feature of one's own physical integrity. This expanded notion of physical harm resonates in women's experience: in the physical and social experience of pregnancy and in the socially constructed experience of motherhood.

Gender has played a complicated role in the evolution of the law of fright-based injury. When gender was ignored - as in assimilating the claims of mothers to bystanders - the law minimized the harm.

218. The critical precedent is Reed v. Reed, 404 U.S. 71 (1971), the first case to declare a state law unconstitutional on grounds of sex discrimination. The constitutional developments are canvassed in $\mathrm{H}$. KAY, supra note 123, at 13-185.

219. Custodio v. Bauer, 251 Cal. App. 2d 303, 59 Cal. Rptr. 463 (1967). For a discussion of the tort of wrongful birth, see Bernier, Mothers as Plaintiffs in Prenatal Tort Liability Cases: Recovery for Physical and Emotional Damages, 4 HARV. WOMEN's L.J. 43 (1981). 
Historically, taking account of gender has also been problematic. Those judges and commentators who noticed gender often failed to appreciate that their use of gender disadvantaged women. Frightbased injuries suffered by women were "remote" to Victorian-era judges; Leon Green, the realist, did not realize that the marginalization of the claim for emotional harm also disproportionately harmed women; ${ }^{220} \mathrm{Dr}$. H.W. Smith viewed women's fright claims as idiosyncratic and unreasonable.221

That recognizing difference may lead to marginalization, while ignoring difference may lead to inequitable results, has long been the Scylla and Charybdis of feminist theory. A major goal of feminist theory is to find a route past these monsters:222 first, by being skeptical of conceptual dualisms enshrined in familiar cultural and legal practice, and second, by unmasking claims of difference to reveal unstated norms against which difference is judged. Dualisms are by their nature restrictive. Indeed, the history of women has been confined by dualisms - home versus market, household versus state - as has the history of the relationship between men and women - public versus private, culture versus nature, defender versus protected. These dualisms have traditionally been expressed in the language of "separate spheres," a series of metaphors that impose dichotomy on understandings of relationships and interactions. To speak of "women's culture" and "men's culture" or, as de Tocqueville did, "two clearly distinct lines of action" 223 for the two sexes is to leave unexamined the interrelationship of the activities included in each collective noun, constructing a vague and unspecified array of allegedly fundamental differences between women and men. Men and women have been enmeshed in a system of meaning and law that, while aiming at equity, discounted and failed to recognize claims associated with women and their interests. To be locked into a series of dualisms that pose men against women and equality against difference inhibits our ability to establish context and to perceive hidden relationships of dominance and subordination..$^{224}$

220. See supra Part VI.

221. See supra Part VII.

222. For discussions of possible ways out of this double bind, see Law, Rethinking Sex and the Constitution, 132 U. PA. L. REv. 955 (1984); Minow, Foreword: Justice Engendered, 101 HARV. L. REv. 10 (1987); Scott, Deconstructing Equality-Versus-Difference: Or, the Uses of Post-Structuralist Theory for Feminism, 14 FEMINIST STUD. 33 (1988); see also Williams, Deconstructing Gender, 87 MiCH. L. REV. 797 (1989).

223. 2 A. DE Tocqueville, Democracy IN America 212 (P. Bradley ed. 1945).

224. See Kerber, Separate Spheres, Female Worlds, Woman's Place: The Rhetoric of Women's History, 75 J. AM. HIST. 9, 37-39 (1988). 
In tort law, the dualism of physical and emotional harm has obscured how courts and commentators used injuries associated with men as the dominant standard for determining legal value. This privileging had the effect of devaluing injuries associated with women, albeit expressed differently in different historical periods. The inequity of the doctrines comprising the law of fright not surprisingly reflected and reinforced inequities present in the larger social and cultural settings. Tort law began to respond to women's interests at a transitional moment in which the cold war's reification of domesticity began to give way to the contemporary women's movement for social change.

The marginalization of the harm suffered by women in the law of fright is not unique. This account of tort law complements scholarship that focuses on other systematic biases in the law, particularly those of race or class. Increasingly, legal scholars have chosen to examine a host of seemingly neutral tort doctrines in search of latent systematic biases against less privileged groups. ${ }^{225}$ In constructing a gendered history of the law of fright, we have attempted to illustrate some important conceptual and linguistic mechanisms that have been used at different times to marginalize women's suffering.

Dillon is important for its part in opening up the legal category of emotional harm. In its contemporary degendered form, the Dillon cause of action not only allows both mothers and fathers to recover for fright, but shakes the general categories of fright and emotions from their confined gendered origins. Women have been hurt by the classification of their fright-based physical harm as emotional disturbance. The privileging of tangible interests over intangible interests reflects the disparate power of those with property, not simply the differing nature of the interests at stake. Emotional harm has been distorted by gendering it female.

225. Richard Abel's work is important here for his emphasis on class bias in tort doctrine. See, e.g., Abel, Should Tort Law Protect Property Against Accidental Loss?, 23 SAN Diego L. Rev. 79 (1986); Abel, Torts, in THE Politics of LAW 185 (D. Kairys ed. 1982). Regina Austin's analysis of the tort of intentional infliction of mental distress examines interlocking systems of race, gender, and class bias. Austin, Employer Abuse, Worker Resistance, and the Tort of Intentional Infiction of Emotional Distress, 41 STAN. L. REv. 1 (1988); see also Delgado, Words that Wound: A Tort Action for Racial Insults, Epithets, and Name-calling, 17 HARv. C.R.-C.L. L. REv. 133 (1982). Jean Love summarizes developments in feminist torts scholarship in Love, Bringing Gender into the Torts Course, AALS Newsletter, Torts-Compensation Systems, at 4-8 (1989). 